\title{
Seasonal Evolution and Variability Associated with the West African Monsoon System
}

\author{
Guojun $G u^{*}$ \\ Goddard Earth Sciences and Technology Center, \\ University of Maryland Baltimore County, and Laboratory for Atmospheres, \\ NASA/Goddard Space Flight Center, Greenbelt, MD, USA \\ Robert F. Adler \\ Laboratory for Atmospheres, \\ NASA/Goddard Space Flight Center, Greenbelt, MD, USA
}

August 2003

Journal of Climate

\footnotetext{
${ }^{*}$ Corresponding author's address: Dr. Guojun Gu, Code 912, Goddard Space Flight Center, Greenbelt,
} MD 20771, USA. E-mail: ggu@agnes.gsfc.nasa.gov 


\section{Seasonal Evolution and Variability Associated with the West African Monsoon System}

Guojun Gu and Robert F. Adler

\section{$\underline{\text { Popular Summary }}$}

Seasonal variations in surface rainfall and associated large-scale processes in the tropical eastern Atlantic and West African region are examined by using the TRMM rainfall and other satellite observations. Major mean rainfall over West Africa tends to be concentrated in two regions and is observed in two different seasons, manifesting an abrupt shift of the mean rainfall zone during June-July. (i) Near the Gulf of Guinea (about $5^{\circ} \mathrm{N}$ ), intense convection and rainfall are observed during April-June. (ii) Along the latitudes of about $10^{\circ} \mathrm{N}$ over the interior West African continent, a second intense rain belt begins to develop from July and remains there during the later summer season.

It is suggested that these two mean rainfall zones are related to two distinct physical processes. Convection and rainfall in the Gulf of Guinea primarily follow the variations of sea surface temperature (SST) in the tropical eastern Atlantic; intense rainfall events within the interior West Africa, primarily within the ITCZ rain band, are mostly associated with the variation and evolution of the large-scale mean wind and the African easterly wave (AEW) activity. The conclusions are very beneficial to the studies of the Atlantic-West African climate and Atlantic hurricane activity. 


\begin{abstract}
In this study, we investigate the seasonal variations in surface rainfall and associated large-scale processes in the tropical eastern Atlantic and West African region. The 5-yr (1998-2002) high-quality TRMM rainfall, sea surface temperature (SST), water vapor and cloud liquid water observations are applied along with the NCEP/NCAR reanalysis wind components and a 3-yr (2000-2002) QuickScat satellite-observed surface wind product.

Major mean rainfall over West Africa tends to be concentrated in two regions and is observed in two different seasons, manifesting an abrupt shift of the mean rainfall zone during June-July. (i) Near the Gulf of Guinea (about $5^{\circ} \mathrm{N}$ ), intense convection and rainfall are seen during April-June and roughly follow the seasonality of SST in the tropical eastern Atlantic. (ii) Along the latitudes of about $10^{\circ} \mathrm{N}$ over the interior West African continent, a second intense rain belt begins to develop from July and remains there during the later summer season. This belt co-exists with a northwardmoved African Easterly Jet (AEJ) and its accompanying horizonal and vertical shear zones, the appearance and intensification of an upper tropospheric Tropical Easterly Jet (TEJ), and a strong low-level westerly flow. Westward-propagating wave signals [i.e., African easterly waves (AEWs)] dominate the synoptic-scale variability during July-September, in contrast to the evident eastward-propagating wave signals during May-June.

The abrupt shift of mean rainfall zone thus turns out to be a combination of two different physical processes: (i) Evident seasonal cycles in the tropical eastern Atlantic ocean which modulate convection and rainfall in the Gulf of Guinea by means of SST thermal forcing and SST-related meridional gradient; (ii) The interaction among the AEJ, TEJ, low-level westerly flow, moist convection and AEWs during July-September which modulates rainfall variability in the interior West Africa, primarily within the ITCZ rain band. Evident seasonality in synoptic-scale wave signals is shown to be a good evidence for this seasonal evolution.
\end{abstract}




\section{Introduction}

Marked seasonal cycle exists in both the surface rainfall and large-scale environment over the West African region (e.g., Grist and Nicholson 2001, Le Barbe et al. 2002, Nicholson and Grist 2003). Major intense rainfall events appear in the Gulf of Guinea from April, move to the latitudes of about $10^{\circ} \mathrm{N}$ during the boreal summer, and then retreat back to the south after mid-September-October, manifesting the seasonal march of the ITCZ (e.g., Sultan and Janicot 2000, Le Barbe et al. 2002, Redelsperger et al. 2002). Time-latitude diagrams of monthly mean rainfall indicate that this seasonal migration is characterized surprisingly by an abrupt shift of the major rain zone during June-July (Fig. 1; Sultan and Janicot 2000, Le Barbe et al. 2002, Redelsperger et al. 2002).

Sultan and Janicot (2000) first emphasized this phenomenon and showed that this shift may be associated with a westward-moving monsoon depression with a period of $20-40$ days. However, what the physical mechanism for this monsoon depression is and how it interacts with the seasonal migration of the ITCZ are not clear. Redelsperger et al. (2002) also noticed this intraseasonal phenomenon accompanying the northward movement of the $\mathrm{AEJ}$, even though the main purpose of their study was to describe multi-scale convective activities within a synoptic-scale system. Le Barbe et al. (2002) detailed the annual cycle of rainfall in West Africa using long-record surface gauge data from 1950 to 1990 . They discovered the existence of (i) two rainy season regimes near the Gulf of Guinea during April-June and (ii) one single rainy season regime in the north around $10^{\circ} \mathrm{N}$ during the later summer season. They proposed that two different dynamics may be in effect: One is associated with the continuous development of rain events near the Gulf of Guinea from February to May. The other is an abrupt surge in mid-June with intense rainfall occuring synchronously between $9^{\circ} N-13^{\circ} N$. Despite the nonlinear monsoon theory (Eltahir and Gong 1996) proposed to be a possible explanation for this phenomenon, no further details were pursued in their study. Lebel et al. (2003) categorized these two rainfall zones as "oceanic" and "continental", suggesting their different physics. However, related processes behind this phenomenon remain unclear and need to be quantified. This quantification will 
certainly enhance our understanding of certain fundamental mechanisms modulating rainfall variability over West Africa on both seasonal and interannual time scales.

A further detailed examination of surface rainfall on the weekly time scale shows that the abrupt shift or "jump" of major rain belts is actually a manifestation of the onset of intense convection and rainfall along $10^{\circ} \mathrm{N}$ and a simultaneous, sudden termination of intense convection and rainfall in the Gulf of Guinea $\left(5^{\circ} \mathrm{N}\right)$ during the time period June-July (Fig. 6a). This seems to support that two various processes are active near the latitudes of $5^{\circ} \mathrm{N}$ and $10^{\circ} \mathrm{N}$, respectively, and the peak rainfall seasons favored by these two processes are different due to different seasonal evolutions in the large-scale environment.

During the time period July-September, large-scale atmospheric circulation features and changes, such as the AEJ and TEJ etc., are commonly considered the major factors influencing rainfall variability in the mean rain band, hence possibly setting the onset of surface rainfall along the latitude of $10^{\circ} \mathrm{N}$ within the interior West Africa (e.g., Nicholson and Grist 2003). High-frequency rainfall variability is significantly modulated by westward-propagating synoptic-scale waves [i.e., African easterly waves (AEW)] (e.g., Burpee 1972, 1974), and also heavily contributed by numerous intense mesoscale convective systems encouraged by the AEJ-related vertical shear (e.g., Rowell and Milford 1993, Laing and Fritsch 1993). Considering the peculiar rainfall transition pattern during June-July (Figs. 1 and 6a), it is interesting to examine whether a similar seasonal variation would exist in various dynamic features.

As an effective forcing mechanism for the tropical atmospheric circulation, global sea surface temperature (SST) patterns and time-changes have been shown to play an essential role in rainfall variability over West Africa on the interannual time scale (e.g., Lamb and Peppler 1992, Fontaine and Janicot 1996, Janicot et al. 1998], particularly the SST anomalies in the tropical eastern Pacific (mostly associated with the ENSO events), and tropical eastern and northeastern Atlantic. On the seasonal time scale, the evident seasonal cycle in the tropical eastern Atlantic thus may naturally be a direct forcing mechanism on rainfall variability at least in the Gulf of Guinea. Opoku-Ankomah and Cordery (1994) reported that a strong 
positive correlation exists between the SST in the tropical eastern Atlantic and rainfall variability in Ghana just north of the coastline in the Gulf of Guinea. In this study, therefore, we will argue that seasonal variations in the surface rainfall near the Gulf of Guinea, where the rainfall peaks during May-June, are primarily modulated by the seasonal forcing from the ocean. In contrast, the rainfall and variability within the interior West Africa primarily result from the interactions among various dynamic components partly shown in previous studies (e.g., Nicholson and Grist 2003).

The paper is organized as follows: Section 2 describes the datasets used in this study. Seasonal variations in the tropical eastern Atlantic and West Africa are presented in Section 3 , which includes detailed descriptions of the evolution of the cold tongue complex on the monthly and weekly time scales by means of the recently available satellite observations, and the seasonal cycle in mean zonal wind field over the tropical eastern Atlantic and West African sector. Synoptic-scale rainfall variability is also investigated in Section 3 by applying a 2-d wavelet spectrum analysis (Gu and Zhang 2001). In Section 4, the main results are summarized and discussed.

\section{Data}

Two 5-year (1998-2002) TRMM products [3B43 (monthly) and 3B42 (daily)] are applied to quantify the seasonal variation of rainfall patterns and associated synoptic-scale perturbations within the West African Monsoon region. These two TRMM datasets are produced by using (nearly) coincident TRMM Combined Instrument (TCI) [the combined TRMM Microwave Imager (TMI) and Precipitation Radar (PR) algorithms] and TRMM Visible and InfraRed (IR) Scanner (VIRS) data to calibrate geosynchronous IR rain rates (Adler et al. 2000 ), providing much better rain rate estimates than those solely derived from the geo-IR observations, but with the same superior time sampling. Both datasets are on a $1^{\circ} \times 1^{\circ}$ grid, cover a global belt approximately from $40^{\circ} S-40^{\circ} \mathrm{N}$, and extend from January 1, 1998 to December 31,2002 . In this study, we will concentrate on the rainfall variability within the 
region of about $9.5^{\circ} \mathrm{W}-9.5^{\circ} \mathrm{E}$ over West Africa and the tropical eastern Atlantic to limit the effects of the western coast and central Africa.

The SST data are retrieved from the TMI on board the TRMM satellite. With a distinct advantage over the traditional IR estimates that require a cloud-free field of view, TMI provides a continuous coverage of tropical SST (Wentz et al. 2000). The data covers a global region extending from $40^{\circ} S$ to $40^{\circ} N$ at a spatial resolution of $0.25^{\circ}$. Monthly and weekly TMI SST products are applied in this study, together with the columnar water vapor and cloud liquid water data retrieved also from the TMI [Detailed algorithms are described in Wentz (1997)]. The spatial patterns and seasonal variations in TMI SST in the tropical Atlantic are further compared to those described by Reynolds and Smith SST data which covers $89.5^{\circ} S-89.5^{\circ} \mathrm{N}$ and on $1^{\circ}$ grid (Reynolds and Smith 1994).

Surface wind fields are obtained from the SeaWinds scatterometer on board the QuickScat satellite (Liu et al. 1998, Liu 2002). Monthly and weekly products from 2000 to 2002 are applied, extending from $89.875^{\circ} S-89.875^{\circ} \mathrm{N}$ and with a spatial resolution of $0.25^{\circ}$.

Monthly zonal wind components from the National Centers for Environmental Prediction (NCEP) and National Center for Atmospheric Research (NCAR) reanalysis project (Kalnay et al. 1996) are used to provide a description of large-scale circulation patterns over the tropical Atlantic and West African region. Archived on a $2.5^{\circ} \times 2.5^{\circ}$ grid, only data from 1998 to 2002 are applied corresponding to the current record-length of the TRMM 3B43 and 3B42.

\section{Results}

Spatial distributions of monthly mean rainfall, SST and surface wind vectors over the Atlantic-African sector are shown in Fig. 2. The oceanic ITCZ, represented by a rainfall band, moves northward and gradually intensifies during boreal spring-summer. It reaches its northernmost position and becomes strongest in August, then retreats back to the south and weakens thereafter. This oceanic ITCZ is generally colocated with warmer SST $\left(>27^{\circ} \mathrm{C}\right)$ 
and surface confluence line. Particularly, with the formation and intensification of a cold tongue in the tropical eastern Atlantic during June-August, the major rainfall zone in the Gulf of Guinea seems to move along the coastline to the western coast not directly northward, roughly following the movement of warmer $\operatorname{SST}$ zone $\left(>27^{\circ} \mathrm{C}\right)$, suggesting the modulation of rainfall by both the land surface and SST-related processes. The land surface conditions north of the coastline in the Gulf of Guinea may not be favorable for the development of rainfall events during this time period. This is quite different from the situations in the eastern Pacific where the ITCZ-related mean rainfall band moves continuously to the north during boreal spring-summer.

Within the West African continent, intense rainfall appears in April right across the coastline in the Gulf of Guinea (Figs. 1 and 2). The mean rainfall band becomes strong in June, but still remains in the coastal region $\left(5^{\circ} N\right)$. In August, the most intense rainfall band has already moved to the latitudes of about $10^{\circ} \mathrm{N}$. Land rainfall retreats back to the south and becomes weaker during boreal fall-winter. Major rainfall events in the Gulf of Guinea are observed mostly over the ocean in December (Fig. 2), corresponding to the coming back of relatively warmer SST in the Gulf of Guinea due to surface wind relaxation (e.g., Weingartner and Weisberg 1991). Between June and August, the major rainfall band does not show a continuous march to the north, and instead two rainfall zones seem to appear independently at two different latitudinal belts $\left(5^{\circ} \mathrm{N}\right.$ and $\left.10^{\circ} \mathrm{N}\right)$ (Fig. 1). As proposed in Section 1, these two rainfall zones may be modulated by two different physical processes. Detailed seasonal variations in various variables are thus investigated in the following two subsections to explore the related physical processes. A 2-d wavelet spectrum analysis is further applied to examine the various components in these two rainfall zones.

\subsection{Cold tongue complex}

\section{a. Monthly mean}

Fig. 2 provides a basic pattern of seasonal evolutions in SST in the tropical Atlantic. In 
the Gulf of Guinea, SST reaches its maximum in April and minimum in August, showing the life cycle of the cold tongue complex. Detailed monthly changes are given in Fig. 3 for the time period February-August, the most intense rainfall transition season. During FebruaryApril, surface rainfall increases along the oceanic ITCZ and in the Gulf of Guinea. Surface wind changes a little, and only a weak northerly acceleration can be seen in the middle of the tropical Atlantic. SST increases in most of the tropical Atlantic except the regions right off the western coast and north of $15^{\circ} \mathrm{N}$. From April to June, significant rainfall increases are seen between $5^{\circ} N-15^{\circ} N$, with sharp decreases south of about $5^{\circ} N$. Simultaneously, an evident acceleration of southerly wind appears. SST drops south of about $5^{\circ} \mathrm{N}$, especially in the Gulf of Guinea, indicating the oncoming cold phase. SST increases north of $5^{\circ} \mathrm{N}$, mostly off the western coast and north of $15^{\circ} \mathrm{N}$. It is interesting to note that an observable negative rainfall change occurs between $5^{\circ} N-10^{\circ} N$ at $0^{\circ} E$, north of the coastline in the Gulf of Guinea, possibly due to unfavorable land surface conditions as we mentioned and/or an indication of a subsidence zone. During June-August, positive rainfall change zone moves farther to the north, concurrently with the positive SST change and southwesterly wind increase. In the Gulf of Guinea, strong negative rainfall changes indicate the termination of major rainfall events, concomitant with the continued SST drop $\left(<27^{\circ} C\right)$. This evolution pattern is basically in agreement with Mitchell and Wallace (1992).

We further narrow our concentration on the domain-mean seasonal cycles in the Gulf of Guinea and the land just north of it between $10^{\circ} \mathrm{W}$ to $10^{\circ} \mathrm{E}$ (Fig. 4). For SST, columnar water vapor (VW), cloud liquid water (LW), and surface wind components, the domain is right across the equator in the eastern Atlantic and approximately covers $4.5^{\circ} S-4.5^{\circ} \mathrm{N}$ and $10^{\circ} \mathrm{W}-5^{\circ} \mathrm{E}$. Two domains are used to represent rainfall variability: (i) $4.5^{\circ} S-6.5^{\circ} \mathrm{N}$, $9.5^{\circ} \mathrm{W}-9.5^{\circ} \mathrm{E}$ and (ii) $4.5^{\circ} \mathrm{S}-4.5^{\circ} \mathrm{N}, 9.5^{\circ} \mathrm{W}-5.5^{\circ} \mathrm{E}$. Annual cycles in rainfall are very similar within these two domains except that a weak semi-annual cycle is seen in the first domain (Fig. 4a), a manifestation of seasonal march of the ITCZ over land. The warmest SST is observed during March-April, with the coldest SST during July-September. We also like to mention that no significant difference is found between TMI SST and Reynolds and 
Smith SST (dashdot and dotted lines in Fig. 4a) except that more details can be seen in the spatial patterns in TMI SST (not shown).

Surface rainfall, VW and LW generally follow the seasonal cycle in SST (Figs. 4a, b), showing the importance of oceanic surface thermal forcing. Previous studies have examined this forcing (e.g., Zhang 1993, Lau et al. 1997). Higher SST tends to induce at least qualitatively more rainfall (e.g., Neelin and Held 1987). However, the peak season in rainfall arrives during April-May and is about a month later than for SST (Fig. 4a). This onemonth-lag possibly leaves space for other factors such as the large-scale circulation to play a role (e.g., Lau et al. 1997). Maloney and Kiehl (2001) showed a similar time-lag of about 10 days between the highest SSTs and maximum convection in the tropical eastern Pacific, which occurs during a composite life cycle of the Madden-Julian oscillation (MJO). Strong surface wind changes during the season March-June are observed by the QuickScat satellite: Zonal wind quickly changes from westerly to easterly (solid line in Fig. 4c), along with a sharp increase of northerly meridional wind (dashdot line in Fig. 4c). These wind changes seem to be a direct response to the convection and rainfall near the coastline (e.g., Mitchell and Wallace 1992; Li and Philander 1997). Due to the shallowness of the thermocline in this part of the ocean, SST is very sensitive to the varying surface wind field (e.g., Merle 1980, Weingartner and Weisberg 1991). The equatorial upwelling process is thus immediately enhanced and SST drops, which eventually forms a cold tongue complex (e.g., Mitchell and Wallace 1992; $\mathrm{Li}$ and Philander 1997). With continued SST drop, rainfall reaches its lowest during July-September, concurrent with the decrease of VW and LW, further showing the impact of SST on convection and rainfall. Hence, surface rainfall in this region actually plays two roles: passively following the seasonal variations in SST, and actively participating in the formation of the equatorial cold tongue and the completion of annual cycle in the entire air-sea coupled system.

\section{b. Weekly mean}

Weekly products from the TRMM satellite are applied to further examine seasonal cycles 
in various variables and their relationships in the Gulf of Guinea (Fig. 5). The SST forcing is evident (Figs. 5a, d and e). Higher (lower) SST generally corresponds to more (less) VW, LW and surface rainfall. Strong linear relations are also seen among VW, LW, and rainfall (Figs. 5b, $\mathrm{c}$ and $\mathrm{f}$ ). Thus, it is not surprising that their linear correlation coefficients are all above the $1 \%$ confidence level based on 50 degree of freedom (dof) (52 weeks per year) (Table 1).

The seasonal variations in rainfall and SST are illustrated in Figs. 6a and b, respectively. Consistent with the monthly results, intense rainfall is observed at two different seasons and two different regions (Figs. 1 and 6a). A sharp reduction of rainfall south of $5^{\circ} \mathrm{N}$ occurs at day 190-200 (i.e., Mid-July), resulting from the cold SST damping. Warmer SST generally corresponds to rainfall events south of $5^{\circ} \mathrm{N}$ within the Gulf of Guinea before the day 190. However, a lag-phase is evident between the maximum rainfall and warmest SST as shown in Fig. 4. It is further noted that the most intense rainfall zone in the region actually comes with the appearance of strong meridional SST gradients (Fig. 6c), despite that the mean SST has to be above a certain threshold (at least $26^{\circ} \mathrm{C}$ ) (Fig. 6b). This suggests the importance of both direct SST forcing and its related dynamic (gradient) forcing in organizing surface convergence, convection and rainfall, generally consistent with previous studies (e.g., Neelin and Held 1987, Lindzen and Nigam 1987).

Weekly surface wind components averaged in the tropical eastern Atlantic are shown in Fig. 7. As in Fig. 4c, the surface wind changes direction from southwesterly to southeasterly around day 120. Particularly, an abrupt increase in the meridional wind component occurs during the days 120-150, confirming the monthly results. Despite high-frequency variabilities in surface wind components on the weekly time scale, coherent relations between zonal and meridional winds are discernible, especially clear in Fig. 7c. Within this region, surface trade wind direction always shifts from southwesterly to southeasterly, or vice versa.

\subsection{Mean zonal wind field}

Previous studies indicate that summer rainfall variability over West Africa is closely 
associated with the variabilities in the large-scale environment on both interannual and seasonal time scales (e.g., Grist and Nicholson 2001, Nicholson and Grist 2003). By using the zonal wind component from the NCEP/NCAR reanalysis project (see comparisons with the QuickScat winds in Appendix), we emphasize the seasonal variations in several dynamic features, e.g., the AEJ, TEJ and low-level flow, etc.

Fig. 8 illustrates the latitude-pressure diagrams of monthly zonal wind between $10^{\circ} \mathrm{W}-$ $10^{\circ} \mathrm{E}$ during March-October. This season approximately covers the entire rainy season over West Africa from the Gulf of Guinea to the northern Sahelian region (Figs. 1 and 6a). The most significant feature in Fig. 8 is the existence of the AEJ at the $600-700 \mathrm{mb}$ level through the year. The AEJ becomes stronger and moves northward during the boreal spring. It achieves its most intensity during May-June. In June, the center of the AEJ is already near $10^{\circ} N$. The AEJ becomes weaker in July and strengthens a little during August-September. It becomes weaker again and moves back to the south during the boreal fall and winter.

Significant seasonal variations can also be found in the low-level westerly flow (Fig. 8). It gradually develops with season and extends its effect to $20^{\circ} \mathrm{N}$ during July-August. The flow reaches its peak during July-September, coincident with the intense rainfall band along $10^{\circ} N$ (Figs. 1 and $6 \mathrm{a}$ ). The same peak season for this low-level westerly flow and surface rainfall strongly suggests their internal connection since the moisture transport from the Gulf of Guinea during this season could have been heavily reduced due to the development of the oceanic cold tongue (Fig. 4). As the AEJ, the low-level flow weakens during the boreal fall and winter.

Given the mean flow pattern shown in Fig. 8, we may further explore to what extent these dynamic features modulate the seasonal variation in surface rainfall. Negative vertical shear, represented by the difference between monthly zonal wind at $600 \mathrm{mb}$ and $925 \mathrm{mb}$ (blue shades in Fig. 9), gradually moves to the north and becomes strong during the boreal spring and summer. The central band of negative shear is roughly corresponding to the locations of surface rainfall. Previous results found that mesoscale systems such as tropical squall lines are important contributors to surface rainfal and the development of these systems are 
closely associated with the existence of vertical wind shear (e.g., Rowell and Milford 1993).

Negative meridional wind shear is favorable for the barotropic energy conversion of mean flow to atmospheric disturbances (i.e., $\frac{d E}{d t}=-\overline{u^{\prime} v^{\prime}} \frac{\partial \bar{u}}{\partial y}>0, E=\frac{1}{2}\left(u^{\prime 2}+v^{\prime 2}\right), \bar{u}$ zonal mean wind, $u^{\prime}$ zonal wind perturbation, $v^{\prime}$ meridional wind perturbation) (Gill 1982; Lau and Lau 1990), given a characteristic southwest to northeast tilt of the AEWs (e.g., Reed et al. 1977). Meridional shears at $600 \mathrm{mb}$, approximately the central level of the AEJ, are estimated (contours in Fig. 9), and significant negative values over West Africa can only be seen in the boreal summer, especially during July-September, the peak season for the AEWs (e.g., Gu and Zhang 2001). Hence, the mean flow seems to influence the surface rainfall variability by modulating the development and strength of the AEWs.

The TEJ is another important summer feature over West Africa because of its associated large-scale upper-level divergent motion. The intense upper tropospheric easterly flow appears in June. The TEJ becomes strongest during July-September, corresponding to the most active AEW and rainy season within the Western African continent. This jet is generally considered to be related to the summer Indian Monsoon processes (e.g., Hastenrath 1991), even though it could exist year-round and move to the southern hemisphere during the boreal winter (Nicholson and Grist 2003).

Fig. 10 further summarizes the seasonal cycles in daily surface rainfall, and zonal wind components at $850 \mathrm{mb}, 600 \mathrm{mb}$, and $150 \mathrm{mb}$ between $10^{\circ} \mathrm{W}-10^{\circ} \mathrm{E}$. A 10-day running mean is applied to remove the high-frequency perturbations. As in Fig. 6a, surface rainfall shows a significant break during the days 180-200 (or June-July). There is an abrupt development in the low-level westerly flow, quantified by the zonal wind at $850 \mathrm{mb}$, which is concomitant with the onset of the rain events along $10^{\circ} \mathrm{N}$. The AEJ moves northward and becomes stronger in the spring as shown in Fig. 8. It becomes weaker during the days 180-200, possibly related to the appearance of the intense AEWs which tend to weaken the AEJ (Fig. 11). As with the low-level westerly flow, a sudden development of the TEJ is also observed approximately at the same time period, i.e., around day 180. These concurrent transition features in these various fields imply their close association. 


\subsection{Rainfall-related perturbations}

In this subsection, we further decompose the surface daily rainfall patterns over the tropical eastern Atlantic and West Africa into various perturbation signals, particularly within the synoptic-scale domain (here referred to wavenumber $k=6-10$ ). The effort is to explore whether any season- and/or latitude-dependent wave modes exist in surface rainfall variability, taking into account the evident seasonal transition of rainfall (Figs. 1, 6a and 10a). A 2-d wavelet spectrum analysis is applied to extract the regional spectral power of perturbations within the wavenumber-frequency domain (Gu and Zhang 2001). Same as in Gu and Zhang (2001), a 92-day running window is applied to estimate the monthly mean spectral power within these five years.

Fig. 11 illustrates the latitude-frequency diagrams of the mean spectral power with $k=6-10$ during April-September. Evident seasonal variations are seen in both the strength of spectral signals and their prefered frequency ranges. Most of the spectral signals move to the north from April to August, following the seasonal migration of major rain events. In April, the perturbation signals are very weak and close to the equator. No dominant propagating signals are discernible in either westward or eastward domain. During May-June,

most propagating signals appear with frequencies $f>0$, i.e., eastward-propagating, and along $2^{\circ} N-6^{\circ} N$. Two major power peaks are located roughly at $f=0.1$ and $f=0.18$ cycles $d a y^{-1}$, respectively. Thus, within the synoptic-scale domain, the rain events at the latitudes of $5^{\circ} \mathrm{N}$ shown in Figs. 1, 6a, and 10a are primarily composed of eastward-propagating perturbations which may be associated with the Kelvin-type tropical waves forced by warm SST (e.g., Wheeler and Kiladis 1999). In contrast, during August-September, westwardpropagating signals are dominant within a frequency band of $-0.1--0.3$ cycles day $^{-1}$, corresponding to the intense AEW activity and major rain events along $10^{\circ} \mathrm{N}$ (Figs. 1, $6 \mathrm{a}$, and $10 \mathrm{a})$. It is interesting to note that westward-propagating and eastward-propagating signals co-exist in July, though the eastward-propagating components are weaker than in May and June. This co-existence seems to be a signature of the sudden transition in the large-scale environment in July detailed in the last two subsections. 
The mean spectral power for those smaller-wavenumber perturbations $(k=1-5)$ is shown in Fig. 12. An evident power peak is seen at a frequency range of $f=0.02-$

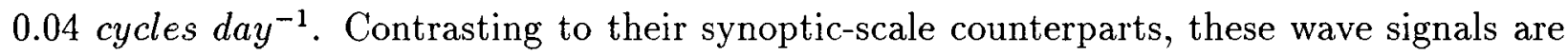
always propagating eastward, though there is a seasonal migration in their prefered latitudes roughly following the seasonal march in surface rainfall. We speculate that these wave signals might be related to the classic tropical intraseasonal variability, i.e., the MJO, though local convection-circulation interactions could also generate the MJO-type oscillation. Since the MJO-related convective signals are considered to be primarily confined in the Indian and western Pacific oceans (i.e., Hendon and Salby 1994) and very little work has been done in the Atlantic-West African sector, detailed mechanisms behind these rainfall perturbations are needed to be quantified in the future. It also needs to be mentioned that the 2-d wavelet spectrum analysis has shown no evidence for the westward-propagating intraseasonal signals proposed in Sultan and Janicot (2000), possibly because these signals are weak and/or can only be observed during a relatively short time period.

\section{Summary and discussion}

The purpose of this study is to understand the seasonal variations in surface rainfall patterns within the West African Monsoon system by means of the 5-yr (1998-2002) high-quality TRMM products, a 3-yr (2000-2002) QuickScat surface wind data, and the NCEP/NCAR reanalysis wind data (1998-2002). Surface mean rainfall tends to be concentrated along two latitudinal belts: $5^{\circ} \mathrm{N}$ and $10^{\circ} \mathrm{N}$ (Figs. 1,6a and 10a). The resulting two peak zones appear in two different seasons: April-June and July-September, respectively. In addition to the mean seasonal march, this pattern is manifested as a major rainfall zone "jump" over West Africa in the time-latitude diagrams as noted in past studies (e.g., Sultan and Janicot 2000, Le Barbe et al. 2002, Redelsperger et al. 2002). Surface rainfall and variability can gener-

ally be related to other large-scale processes. Furthermore, these two peak rainfall zones are actually associated with two different processes. 
Near the Gulf of Guinea (about $5^{\circ} N$ ) (Figs. 1-6), intense rainfall begins in April, apparently following the occurrence of warm SST in the tropical eastern Atlantic. Meridional SST gradients also play an essential role in forcing convection and rainfall during the days 120-190 (approximately from May to mid-July) (Fig. 6c), generally consistent with previous studies (e.g., Lindzen and Nigam 1987, Lau et al. 1997). Low-level southerly flow accelerates, possibly a direct response to the convection and rainfall, which induces the decrease in SST through an enhanced equatorial upwelling. Besides enhancing the southerly flow, the formed cold SST zone quickly begins to suppress the convection and rainfall when the mean SST is less than about $27^{\circ} \mathrm{C}$, though the strong meridional SST gradients still exist till about day 250 (Fig. 6c). The major deep convective zone is pushed northwestward along the coastline following the northward-movement of warm water, rather than gradually moving northward across the land probably due to the unfavorable surface conditions. Consequently the major surface rainfall events near the Gulf of Guinea disappear due to the formation of an oceanic cold tongue complex in the tropical eastern Atlantic. During this evolution, the surface rainfall is shown to be both a passive and an active member in the entire coupled system. Other large-scale factors such as AEJ and TEJ, however, have not shown any significant impact in this region.

Along the $10^{\circ} \mathrm{N}$ within the interior West Africa (Figs. 1, 6a and 10a), a second rain belt begins to develop from July and remains there during the later summer season. This belt seems to be independent of the first one to the south. The onset of rainfall events within this belt is concomitant with a northward-movement of the AEJ and accompanying horizonal and vertical shear zones, the appearance and strengthening of the TEJ and a strong low-level westerly flow, and the appearance of intense westward-propagating synoptic-scale wave signals (Figs. 8-11). Thus, rainfall and variability within the western African continent are primarily modulated by these large-scale features such as the AEJ, TEJ and low-level southwesterly flow (e.g., Grist and Nicholson 2001). However, the indirect dynamic effect of SST may not be neglected. Significant negative correlation between the SST in the tropical eastern Atlantic and the mean rainfall along $10^{\circ} \mathrm{N}$ is found (not shown) as in Opoku- 
Ankomah and Cordery (1994). Additionally, intense surface meridional SST gradients during the days 190-250 are certainly favorable for the surface convergence zone and rainfall along $10^{\circ} N$ (Fig. 6c).

There may also be a connection between the first rainfall peak and the AEJ (Figs. 8 and 10). Thorncroft and Blackburn (1999) indicated the importance of deep moist convection in the maintenance of the AEJ in a numerical simulation. A recent aircraft campaign further showed the modulations of mesoscale convective systems and associated convecting heating on the AEJ (Thorncroft et al. 2003). The results in Figs. 8 and 10 tend to agree with them. Corresponding to the intense convection and rainfall during the boreal spring and early summer, the AEJ becomes very strong, right over or just north of the rainfall zone. The AEJ is directly connected to the appearance of the intense AEWs from July which tend to weaken the intensity of the AEJ, possibly along with the major rain belt "jump" (actually a rainfall decrease) during the day 180-210 period (July). With the increase of surface rainfall along $10^{\circ} \mathrm{N}$ and/or a balance between the impacts of the AEWs and rainfall, the AEJ becomes stronger again during the days 210-270. Thus, in addition to being an active member in the coupled system within the Gulf of Guinea, surface rainfall may also contribute to the evolution of the AEJ.

A 2-d wavelet spectrum analysis further provides a detailed decomposition of surface rainfall variability (Figs. 11 and 12). Most eastward-propagating (intraseasonal and synopticscale) wave signals are observed within the first peak rainfall zone during May-June. During July-September, in contrast, AEWs dominate the variability in the synoptic-scale domain within the second peak zone, even though eastward-propagating intra-seasonal signals are still seen. This wave mode decomposition seems to enhance our argument on the seasonal variations of rainfall patterns over West Africa.

Tai and Ogura (1987) proposed that tropical easterly waves may be responsible for an abrupt $5^{\circ}$ northward movement of surface confluence line between June-July in the eastern Pacific. It seems that the AEWs can also be linked to the onset of rainfall events along the $10^{\circ} \mathrm{N}$ due to their close relationships with the AEJ, TEJ and low-level southwesterly 
flow. The appearance of the AEWs is concurrent with the weakening of the AEJ and the strengthening of the TEJ and low-level southwesterly flow. Hence, these waves may act as a major means for those large-scale features to modulate surface rainfall, especially the locations of rainfall events along $10^{\circ} \mathrm{N}$ where the mean ITCZ is always located during the boreal summer. Certainly, we can not exclude the contributions from other mesoscale systems or random convective ones, though these systems may also be modulated or organized by the AEWs.

Consistent with Lebel et al. (2003), the west African continent may roughly be divided into two regions: south and north of about $6^{\circ} N-7^{\circ} N$. In these two regions, the seasonal cycles in surface rainfall are fundamentally different and modulated by different processes, featuring two different peak rainfall seasons. This division may greatly enhance our understanding of the seasonal rainfall distribution over West Africa and moreover further our knowledge of interannual and/or decadal variability in surface rainfall. However, it has to be pointed out that the conclusions made in this study are mostly based on the direct observations. The actual cause-consequence relationships are much more complicated than we anticipate. Various feedbacks may always be active. Numerical models are required for further clarifications. These conclusions may also be tentative due to the ignorance of soil moisture which may positively interact with rainfall (e.g., Nicholson 2000).

Finally, we mention that the relationship between surface rainfall and SST is evident here even on the weekly time scale, but the detailed mechanisms are far from clear. The 1-month lag between the peak SST and surface rainfall within the Gulf of Guinea clearly indicates the involvement of other factors such as meridional SST gradients and possibly the large-scale motions (e.g., Lau et al. 1997). Further, more quantitative, examination is surely necessary.

\section{Acknowledgements.}

The authors would like to thank Mr. David Bolvin for preparing the TRMM 3B42 and 3B43 data. Both TMI SST, water vapor and cloud liquid water data, and QuickScat sea surface wind (weekly and monthly) data were downloaded from http://www.ssmi.com. 
NCAR/NCEP Reanalysis data were provided by the NOAA-CIRES Climate Diagnostics Center, Boulder, Colorado, USA, from its Web site at http://www.cdc.noaa.gov. This work is supported through the TRMM Science Team under the NASA Headquarters TRMM Program Scientist Dr. Ramesh Kakar.

\section{Appendix: Comparisons of monthly wind products}

Smith et al. (2001) found that the NCEP/NCAR reanalysis surface wind components are underestimated at all latitudes, compared with the World Ocean Circulation Experiment (WOCE) ship observations. Goswami and Sengupta (2003) confirmed it in the tropical Indian Ocean by means of the high-quality QuickScat wind fields. Since the NCEP/NCAR reanalysis wind products, especially zonal wind component, are used to quantify the largescale flow, we like to estimate the differences between them and QuickScat wind observations in the tropical Atlantic.

Seasonal cycles in the NCEP/NCAR $1000 \mathrm{mb}$ wind components are calculated within a domain of $5^{\circ} \mathrm{S}-5^{\circ} \mathrm{N}, 10^{\circ} \mathrm{W}-5^{\circ} \mathrm{E}$ (dashed and dotted lines in Fig. 4c). The NCEP/NCAR $1000 \mathrm{mb}$ zonal wind shows a very similar seasonal cycle as the QuickScat zonal wind, and their difference is approximately less than $1 \mathrm{~m} \mathrm{~s}^{-1}$. However, large differences are found between the QuickScat and NCEP/NCAR $1000 \mathrm{mb}$ meridional winds (dashdot and dotted lines in Fig. 4c), particularly during March-June, which actually results in two different seasonal cycles. Further comparisons are made within a domain in the tropical central Atlantic: $0.125^{\circ} \mathrm{N}-5.125^{\circ} \mathrm{N}, 30.125^{\circ} \mathrm{W}-20.125^{\circ} \mathrm{W}$ for QuickScat winds and $0-5^{\circ} \mathrm{N}, 30^{\circ} \mathrm{W}-20^{\circ} \mathrm{W}$ for the NCEP/NCAR $1000 m b$ winds (Fig. A1), where different seasonal evolution patterns in surface wind fields are found (not shown). The NCEP/NCAR $1000 \mathrm{mb}$ zonal wind seems to be overestimated during March-July but underestimated primarily during SeptemberDecember, a little different from Smith et al. (2001) and Goswami and Sengupta (2003). However, both zonal wind components show a very similar seasonal cycle and their difference

is less than $1 \mathrm{~m} \mathrm{~s}^{-1}$ as in Fig. 4c. For meridional winds, large differences are found during 
May-December. The NCEP/NCAR $1000 \mathrm{mb}$ meridional wind is underestimated about $2-3$ $m s^{-1}$, even though it has a similar seasonal cycle as the QuickScat meridional component. Thus, both Figs. 4c and Al provide confidence in the NCEP/NCAR zonal wind component, but shed suspicions on the application of NCEP/NCAR meridional wind field. 


\section{References}

Adler, R. F., G. J. Huffman, D. T. Bolvin, S. Curtis and E. J. Nelkin, 2000: Tropical rainfall distributions determined using TRMM combined with other satellite and rain gauge information. J. Appl. Meteor., 39, 2007-2023.

Burpee, R. W., 1972: The origin and structure of easterly waves in the lower troposphere of North Africa. J. Atmos. Sci., 29, 77-90.

Burpee, R. W., 1974: Characteristics of the North African easterly waves during the summers of 1968 and 1969. J. Atmos. Sci., 31, 1556-1570.

Duvel, J. P., 1990: Convection over tropical Africa and the Atlantic Ocean during northern summer. Part II: Modulation by easterly waves. Mon. Wea. Rev., 118, 1855-1868.

Eltahir, E. A. B., and C. Gong, 1996: Dynamics of wet and dry years in west Africa. J. Climate, 9, 1030-1042.

Fontaine, B., and S. Janicot, 1996: Sea surface temperature fields associated with West African rainfall anomaly types. J. Climate, 9, 2935-1940.

Gill, A. E., 1982: Atmosphere-Ocean Dynamics. Academic Press, 662pp.

Goswami, B. N., and D. Sengupta, 2003: A note on the deficiency of NCEP/NCAR reanalysis surface winds over the equatorial Indian Ocean. J. Geophys. Res., 108 (C4), 3142, doi:10.1029/2002JC001497.

Grist, J. P., and S. E. Nicholson, 2001: A study of the dynamic factors influencing the rainfall variability in the west African Sahel. J. Climate, 14, 1337-1359.

Gu, G., and C. Zhang, 2001: A spectrum analysis of synoptic-scale disturbances in the ITCZ. J. Climate, 14, 2725-2739.

Hastenrath, S., 1991: Climate Dynamics of the Tropics. Kluwer Academic Publishers, 488 pp.

Hendon, H. H., and M. L. Salby, 1994: The life cycle of the Madden-Julian oscillation. $J$. Atmos. Sci., 51, 2225-2237. 
Janicot, S., A. Harzallah, B. Fontaine, and V. Moron, 1998: West African Monsoon dynamics and eastern equatorial Atlantic and Pacific SST anomalies (1970-1988). J. Climate, 11, 1874-1882.

Kalnay, E., and Coauthors, 1996: The NCEP/NCAR 40-year reanalysis project. Bull. Amer. Meteor. Soc., 77, 437-471.

Laing, A. G., and J. M. Fritsch, 1993: Mesoscale convective complexes in Africa. Mon. Wea. Rev., 121, 2254-2263.

Lamb, P. J., and R. A. Peppler, 1992: Further case studies of tropical Atlantic surface atmospheric and oceanic patterns associated with sub-Saharan drought. J. Climate, 5, 476-488.

Lau, K.-H., and N.-C. Lau, 1990: Observed structure and propagation characteristics of tropical summertime synoptic scale disturbances. Mon. Wea. Rev., 118, 1888-1913.

Lau, K.-M., H.-T. Wu, and S. Bony, 1997: The role of large-scale atmospheric circulation in the relationship between tropical convection and sea surface temperature. J. Climate, 10, 381-392.

Le Barbe, L., T. Lebel, and D. Tapsoba, 2002: Rainfall variability in West Africa during the years 1950-90. J. Climate, 15, 187-202.

Lebel, T., A. Diedhiou, and H. Laurent, 2003: Seasonal cycle and interannual variability of the Sahelian rainfall at hydrological scales. J. Geophys. Res., 108 (D8), 8389, doi:10.1029/2001JD001580.

Li, T., and S. G. H. Philander, 1997: On the seasonal cycle of the equatorial Atlantic ocean. J. Climate, 10, 813-817.

Lindzen, R. S., and S. Nigam, 1987: On the role of sea surface temperature gradients in forcing low-level winds and convergence in the Tropics. J. Atmos. Sci., 44, 2418-2436.

Liu, W. T., 2002: Progress in scatterometer application. J. Oceanogr., 58, 121-136.

Liu, W. T., W. Tang, and P. S. Polito, 1998: NASA Scatterometer provides global oceansurface wind fields with more structures than numerical weather prediction. Geophys. Res. Lett., 25, 761-764. 
Maloney, E. D., and J. T. Kiehl, 2002: MJO-related SST variability over the tropical eastern Pacific during Northern Hemisphere summer. J. Climate, 15, 675-689.

Merle, J., 1980: Seasonal heat budget in the equatorial Atlantic ocean. J. Phys. Oceanogr., 10, 464-469.

Mitchell, T. P., and J. M. Wallace, 1992: The annual cycle in equatorial convection and sea surface temperature. J. Climate, 5, 1140-1156.

Neelin, J. D., and I. M. Held, 1987: Modeling tropical convergence based on the moist static energy budget. Mon. Wea. Rev., 115, 3-12.

Nicholson, S. E., 2000: Land surface processes and Sahel Climate. Rev. Geophys., 38, $117-139$.

Nicholson, S. E., and J. P. Grist, 2003: The seasonal evolution of the atmospheric circulation over West Africa and equatorial Africa. J. Climate, 16, 1013-1030.

Opoku-Ankomah, Y., and I. Cordery, 1994: Atlantic sea surface temperatures and rainfall variability in Ghana. J. Climate, 7, 551-558.

Redelsperger, J.-L., A. Diongue, A. Diedhiou, J.-P. Ceron, M. Diop, J.-F Gueremy, and J.-P. Lafore, 2002: Multi-scale description of a Sahelian synoptic weather system representative of the West African Monsoon, Quart. J. Roy. Meteor. Soc., 128, 1229-1257.

Reed, R. J., D. C. Norquist, and E. E. Recker, 1977: The structure and properties of African wave disturbances as observed during Phase III of GATE. Mon. Wea. Rev., 105, 317-333.

Reynolds, R. W., and T. M. Smith, 1994: Improved global sea surface temperature analyses using optimum interpolation. J. Climate, 7, 929-948.

Rowell, D. P., and J. R. Milford, 1993: On the generation of African squall lines. J. Climate, 6, 1181-1193.

Smith, S. R., D. M. Lehler, and K. V. Verzone, 2001: Quantifying uncertainties in NCEP reanalyses using high-quality research vessel observations. J. Climate, 14, 4062-4072.

Sultan, B. and S. Janicot, 2000: Abrupt shift of the ITCZ over West Africa and intraseasonal variability. Geophys. Res. Lett., 27, 3353-3356. 
Tai, K.-S., and Y. Ogura, 1987: An observational study of easterly waves over the eastern Pacific in the northern summer using FGGE data. J. Atmos. Sci., 44, 339-361.

Thorncroft, C. D., and M. Blackburn, 1999: Maintenance of the African easterly jet. Quart. J. Roy. Meteor. Soc., 125, 763-786.

Thorncroft, C. D., and Coauthors, 2003: The JET2000 project. Bull. Amer. Meteor. Soc., 84, 337-351.

Weingartner, T. J., and R. H. Weisberg, 1991: A description of the annual cycle in sea surface temperature and upper ocean heat in the equatorial Atlantic. J. Phys. Oceanogr., 21, 83-96.

Wentz, F. J., 1997: A well-calibrated ocean algorithm for special sensor microwave/imager. J. Geophys. Res., 102, 8703-8718.

Wentz, F. J., C. Gentemann, D. Smith, and D. Chelton, 2000: satellite measurements of sea surface temperature through clouds. Science, 288, 847-850.

Wheeler, M., and G. N. Kiladis, 1999: Convectively coupled equatorial waves: Analysis of clouds and temperature in the wavenumber-frequency domain. J. Atmos. Sci., 56, 374-399.

Zhang, C., 1993: Large-scale variability of atmospheric deep convection in relation to sea surface temperature in the Tropics. J. Climate, 6, 1898-1912. 


\section{List of Tables}

1 Correlation coefficients $(\gamma)$ between weekly rainfall $\left[P\left(\mathrm{~mm} \mathrm{day}^{-1}\right) ; 4.5^{\circ} S-\right.$ $\left.6.5^{\circ} \mathrm{N}, 9.5^{\circ} \mathrm{W}-9.5^{\circ} \mathrm{E}\right)$, TMI SST $\left[{ }^{\circ} \mathrm{C} ; 4.125^{\circ} \mathrm{S}-4.125^{\circ} \mathrm{N}, 10.125^{\circ} \mathrm{W}-5.125^{\circ} \mathrm{E}\right]$, columnar water $\left[V W(\mathrm{~mm}) ; 4.125^{\circ} \mathrm{S}-4.125^{\circ} \mathrm{N}, 10.125^{\circ} \mathrm{W}-5.125^{\circ} \mathrm{E}\right]$, and cloud liquid water $\left[\mathrm{LW}(\mathrm{mm}) ; 4.125^{\circ} \mathrm{S}-4.125^{\circ} \mathrm{N}, 10.125^{\circ} \mathrm{W}-5.125^{\circ} \mathrm{E}\right]$ during 1998-2002. $\gamma=0.354$ is the $1 \%$ confidence level based on .50 degree of freedom

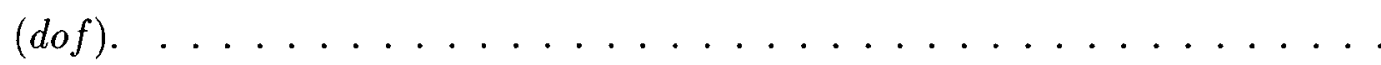




\section{List of Figures}

1 Monthly mean rainfall $\left(m m d a y^{-1}\right)$ between $9.5^{\circ} \mathrm{W}-9.5^{\circ} \mathrm{E}$ as function of month and latitude during 1998-2002. . . . . . . . . . . . . 27

2 Monthly mean rainfall $\left(m m d a y^{-1}\right)$ from $3 \mathrm{~B} 43$ (color shades), TMI SST $\left({ }^{\circ} \mathrm{C}\right.$; contours), and QuickScat wind vectors $\left(m s^{-1}\right.$, only from 2000 to 2002$)$ in the Atlantic-West African sector. Wind vectors of magnitudes $<0.5 \mathrm{~ms}^{-1}$ are

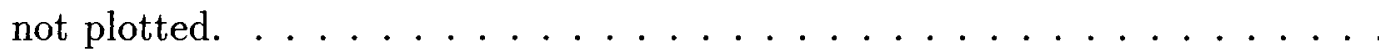

3 Monthly changes in mean rainfall $\left(m m d a y^{-1}\right)$ from 3B43, TMI SST $\left({ }^{\circ} \mathrm{C}\right)$ and QuickScat wind vectors $\left(\mathrm{ms}^{-1}\right.$; only from 2000 to 2002$)$ in the Atlantic-African sector. Wind change vectors of magnitudes $<0.5 \mathrm{~ms}^{-1}$ are not plotted. . .

4 Seasonal cycles in (a) rainfall $\left[P\left(m m d a y^{-1}\right)\right]$ from $3 B 43\left[4.5^{\circ} S-6.5^{\circ} \mathrm{N}\right.$, $9.5^{\circ} \mathrm{W}-9.5^{\circ} \mathrm{E}$ (solid line); $4.5^{\circ} \mathrm{S}-4.5^{\circ} \mathrm{N}, 9.5^{\circ} \mathrm{W}-5.5^{\circ} \mathrm{E}$ (dashed line)], TMI SST $\left({ }^{\circ} \mathrm{C}\right)\left(4.125^{\circ} \mathrm{S}-4.125^{\circ} \mathrm{N}, 10.125^{\circ} \mathrm{W}-5.125^{\circ} \mathrm{E}\right.$; dashdot line $)$, and Reynolds and Smith SST $\left({ }^{\circ} \mathrm{C}\right)\left(4.5^{\circ} S-4.5^{\circ} \mathrm{N}, 9.5^{\circ} \mathrm{W}-4.5^{\circ} E\right.$; dotted line), (b) TMI columnar water vapor ( $V W(\mathrm{~mm})$; solid line) and cloud liquid water [LW $(\mathrm{mm}) ;$ dashed line $]\left(4.125^{\circ} \mathrm{S}-4.125^{\circ} \mathrm{N}, 10.125^{\circ} \mathrm{W}-5.125^{\circ} \mathrm{E}\right)$, and (c) QuickScat zonal $\left(U\left(m s^{-1}\right)\right.$; solid line $)$ and meridional winds $\left[V\left(m s^{-1}\right)\right.$; dashdot line] $\left(4.125^{\circ} S-4.125^{\circ} \mathrm{N}, 10.125^{\circ} \mathrm{W}-5.125^{\circ} \mathrm{E}\right)$, and NCEP/NCAR $1000 \mathrm{mb}$ zonal $\left[U\left(m s^{-1}\right)\right.$; dashed line] and meridional winds $\left[V\left(m s^{-1}\right)\right.$; dotted line] $\left(5^{\circ} S-5^{\circ} \mathrm{N}, 10^{\circ} \mathrm{W}-5^{\circ} \mathrm{E}\right)$. (c) is only from 2000 to 2002 . . . .

5 Scattergrams of weekly rainfall $\left[P\left(m m\right.\right.$ day $\left.\left.^{-1}\right) ; 4.5^{\circ} S-6.5^{\circ} \mathrm{N}, 9.5^{\circ} \mathrm{W}-9.5^{\circ} \mathrm{E}\right)$, TMI SST $\left[{ }^{\circ} C ; 4.125^{\circ} S-4.125^{\circ} N, 10.125^{\circ} W-5.125^{\circ} E\right]$, columnar water $[V W$ $\left.(\mathrm{mm}) ; 4.125^{\circ} \mathrm{S}-4.125^{\circ} \mathrm{N}, 10.125^{\circ} \mathrm{W}-5.125^{\circ} \mathrm{E}\right]$, and cloud liquid water $[L W$ $\left.(m m) ; 4.125^{\circ} S-4.125^{\circ} \mathrm{N}, 10.125^{\circ} \mathrm{W}-5.125^{\circ} \mathrm{E}\right]$. Dots are for 1998, crosses for 1999 , circles for 2000 , diamonds for 2001 , and squares for 2002 . . . . . . 
6 Seasonal cycles in (a) weekly rainfall $\left(m m d a y^{-1}\right)$ between $9.5^{\circ} \mathrm{W}-9.5^{\circ} E$, (b) weekly $\mathrm{TMI} \operatorname{SST}\left[{ }^{\circ} \mathrm{C} ; 4.125^{\circ} \mathrm{S}-4.125^{\circ} \mathrm{N}, 10.125^{\circ} \mathrm{W}-5.125^{\circ} \mathrm{E}\right]$, and (c) weekly TMI SST differences between $2.125^{\circ} \mathrm{N}$ and $0.125^{\circ} \mathrm{S}$, averaged along $10.125^{\circ} \mathrm{W}-5.125^{\circ} \mathrm{E}$. In (b) and (c), solid lines are for 1998, dashed lines for 1999, dashdot lines for 2000, dotted lines for 2001, and star lines for 2002 .

$7 \quad$ Weekly mean (a) zonal $(U)$ and meridional $(V)$ wind components $\left(m\right.$ day $\left.{ }^{-1}\right)$ within $4.125^{\circ} \mathrm{S}-4.125^{\circ} \mathrm{N}, 10.125^{\circ} \mathrm{W}-5.125^{\circ} \mathrm{E}$ from QuickScat as function of time; Solid lines are for 2000, dashed lines for 2001, and dashdot lines for 2002. (c) Scattergram of wind components; Dots are for 2000, crosses for 2001 , circles for 2002. . . . . . . . . . . . . . . . .

8 Monthly-mean zonal wind component $\left(m s^{-1}\right)$ from NCEP/NCAR Reanalysis Project between $10^{\circ} \mathrm{W}-10^{\circ} \mathrm{E}(1998-2002)$ as function of pressure and latitude. 34

9 Difference between monthly-mean zonal wind components $\left(\mathrm{ms}^{-1}\right)$ at $600 \mathrm{mb}$ and $925 \mathrm{mb}$ (color shades), meridional shear of monthly-mean zonal wind at $600 \mathrm{mb}$ (proportional to $\mathrm{s}^{-1}$; contours), and wind vectors at $150 \mathrm{mb}$ from NCEP/NCAR Reanalysis Project (wind vectors of magnitude $<0.5 \mathrm{~ms}^{-1}$ are not plotted) (1998-2002). . . . . . . . . . . . . .

10 Seasonal cycles in (a) daily rainfall ( $m m$ day ${ }^{-1} ; 10$-day running mean) from 3B42 between $9.5^{\circ} \mathrm{W}-9.5^{\circ} \mathrm{E}$, and daily zonal wind components $\left(\mathrm{ms}^{-1} ; 10\right.$-day running mean) from NCEP/NCAR Reanalysis Project at (b) $850 \mathrm{mb}$, (c) 600 $m b$ and (d) $150 m b$ between $10^{\circ} W-10^{\circ} \mathrm{E} \ldots \ldots \ldots$

11 Mean spectral power $\left(\mathrm{mm}^{2} d a y^{-2}\right.$; wavenumber $\left.k=6-10\right)$ of rainfall from $3 \mathrm{~B} 42$ between $9.5^{\circ} \mathrm{W}-9.5^{\circ} \mathrm{E}$ during April-September as function of frequency (cycles $d a y^{-1}$ ) and latitude. Positive (negative) frequencies represent eastward

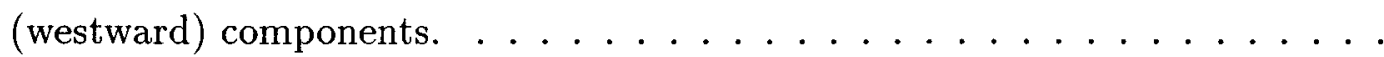


12 Mean spectral power $\left(\mathrm{mm}^{2} d a y^{-2}\right)$ of rainfall from $3 \mathrm{~B} 42$ between $9.5^{\circ} \mathrm{W}-9.5^{\circ} \mathrm{E}$ for $k=1-5$ during (a) April-June and (b) July-September as function of frequency (cycles day ${ }^{-1}$ ) and latitude. Positive (negative) frequencies represent eastward (westward) components. . . . . . . . . . . . . . . .

A1 Monthly mean QuickScat $\left(\mathrm{ms}^{-1}\right.$; solid lines in (a) and (b); $0.125^{\circ} \mathrm{N}-5.125^{\circ} \mathrm{N}$, $\left.30.125^{\circ} \mathrm{W}-20.125^{\circ} \mathrm{W}\right)$ and NCEP/NCAR $1000 \mathrm{mb}$ wind components $\left(\mathrm{ms}^{-1}\right.$; dashed lines in (a) and (b); $0-5^{\circ} \mathrm{N}, 30^{\circ} \mathrm{W}-20^{\circ} \mathrm{W}$ ) from 2000 to 2002 . (a) Zonal wind components; (b) Meridional wind components; (c) The differences between QuickScat and NCEP/NCAR $1000 \mathrm{mb}$ wind components (solid line for zonal wind, dashed line for meridional wind) . . . . . . . . . . . . 
Table 1: Correlation coefficients $(\gamma)$ between weekly rainfall $\left[P\left(m m d a y^{-1}\right) ; 4.5^{\circ} S-6.5^{\circ} \mathrm{N}\right.$, $\left.9.5^{\circ} \mathrm{W}-9.5^{\circ} \mathrm{E}\right)$, TMI SST $\left[{ }^{\circ} \mathrm{C} ; 4.125^{\circ} \mathrm{S}-4.125^{\circ} \mathrm{N}, 10.125^{\circ} \mathrm{W}-5.125^{\circ} \mathrm{E}\right]$, columnar water $\left[V W(\mathrm{~mm}) ; 4.125^{\circ} \mathrm{S}-4.125^{\circ} \mathrm{N}, 10.125^{\circ} \mathrm{W}-5.125^{\circ} \mathrm{E}\right]$, and cloud liquid water $[L W(\mathrm{~mm})$; 4.125 $\left.\mathrm{S}-4.125^{\circ} \mathrm{N}, 10.125^{\circ} \mathrm{W}-5.125^{\circ} \mathrm{E}\right]$ during $1998-2002 . \gamma=0.354$ is the $1 \%$ confidence level based on 50 degree of freedom (dof).

\begin{tabular}{l|c|c|c|c|c}
\hline \hline$\gamma$ & 1998 & 1999 & 2000 & 2001 & 2002 \\
\hline \hline$P$ and $S S T$ & 0.45 & 0.58 & 0.53 & 0.67 & 0.55 \\
\hline$P$ and $V W$ & 0.59 & 0.6 & 0.64 & 0.62 & 0.53 \\
\hline$P$ and $L W$ & 0.69 & 0.81 & 0.67 & 0.76 & 0.74 \\
\hline$V W$ and $S S T$ & 0.89 & 0.86 & 0.83 & 0.87 & 0.87 \\
\hline$L W$ and $S S T$ & 0.61 & 0.66 & 0.49 & 0.57 & 0.52 \\
\hline$L W$ and $V W$ & 0.79 & 0.78 & 0.7 & 0.67 & 0.67 \\
\hline \hline
\end{tabular}




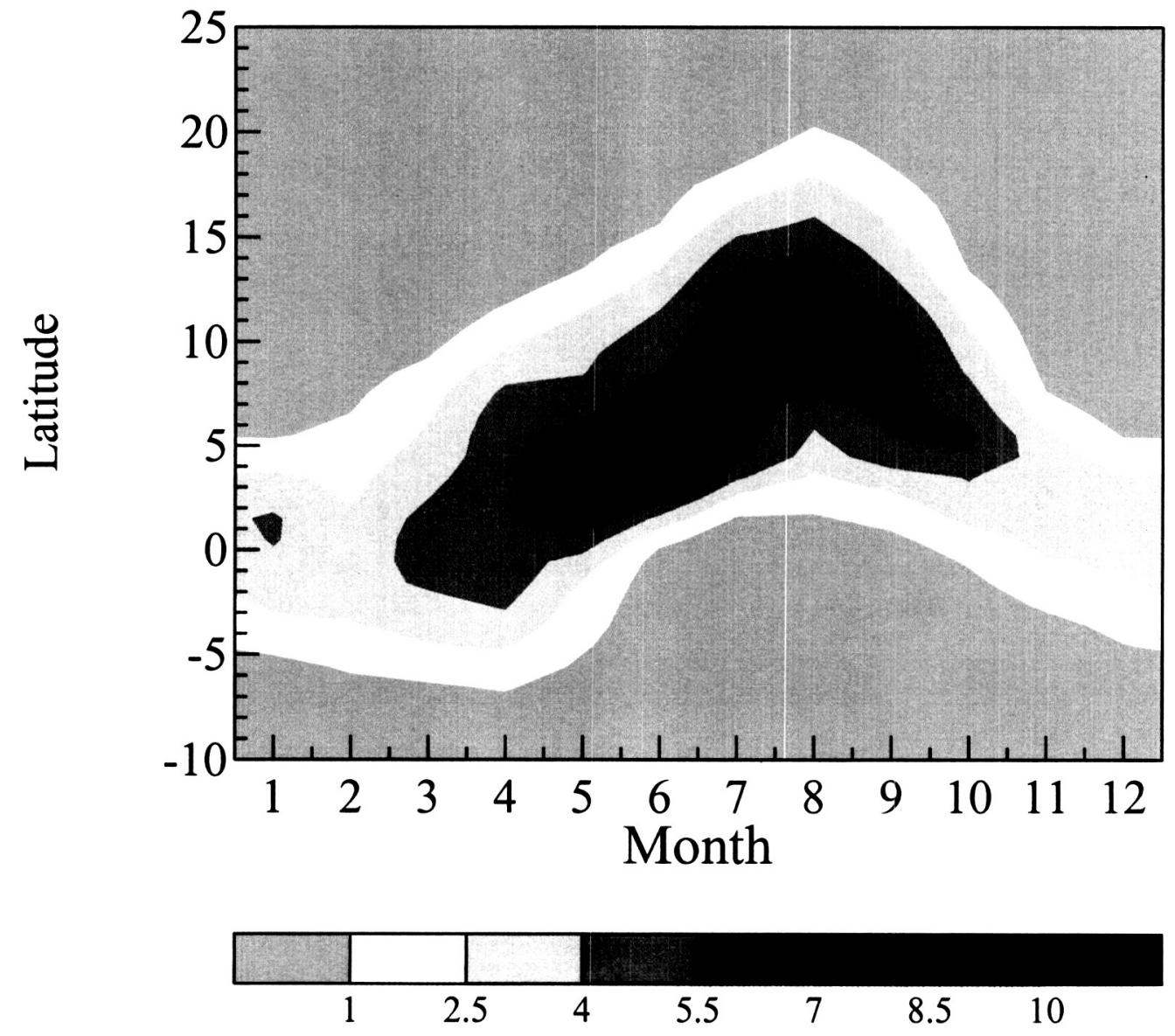

Figure 1: Monthly mean rainfall $\left(\mathrm{mm} \mathrm{day}^{-1}\right)$ between $9.5^{\circ} \mathrm{W}-9.5^{\circ} \mathrm{E}$ as function of month and latitude during 1998-2002. 


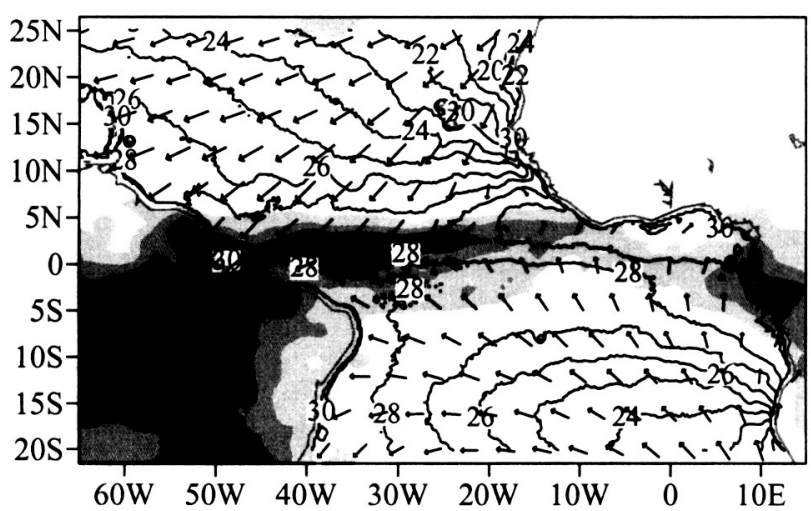

June

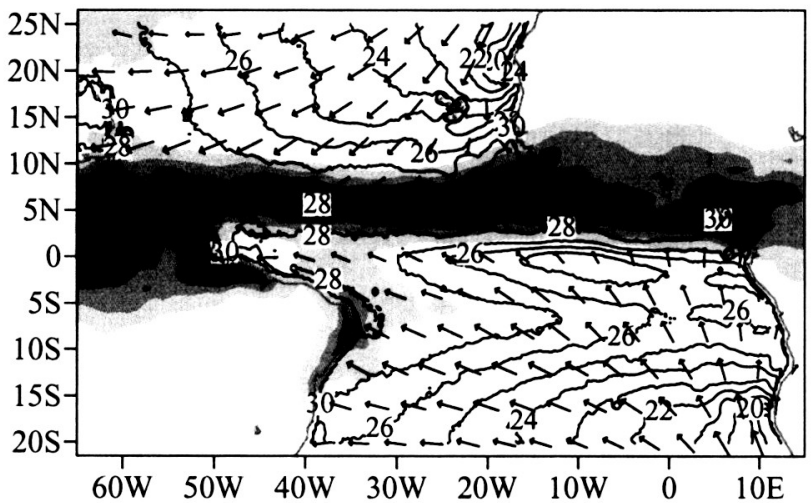

October

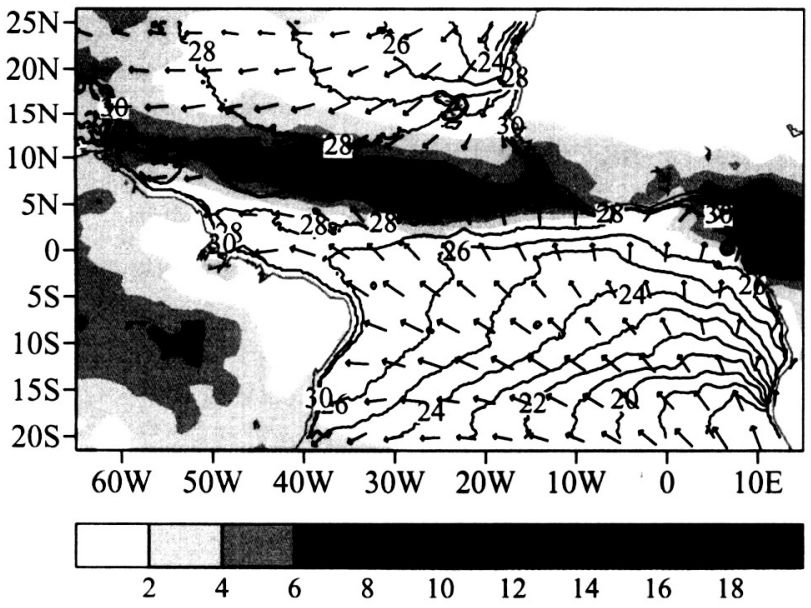

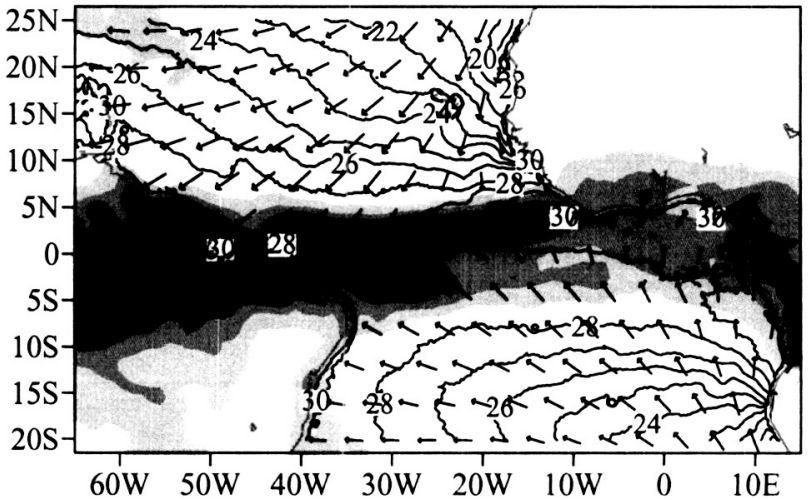

August

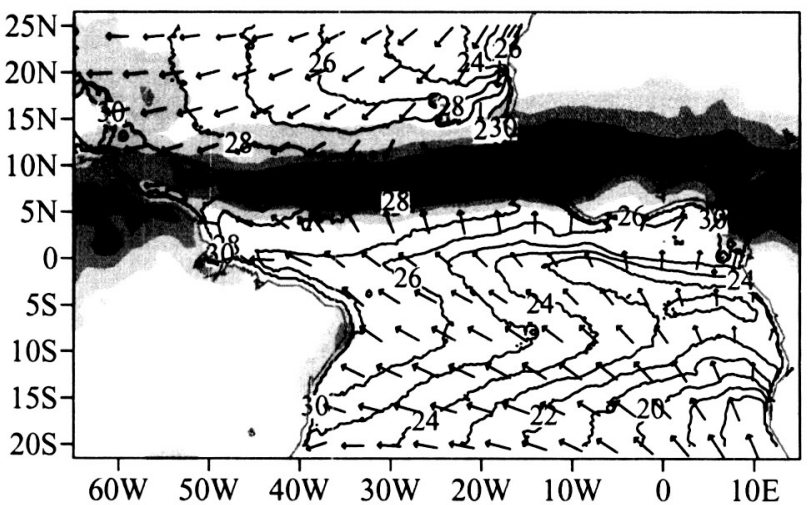

December

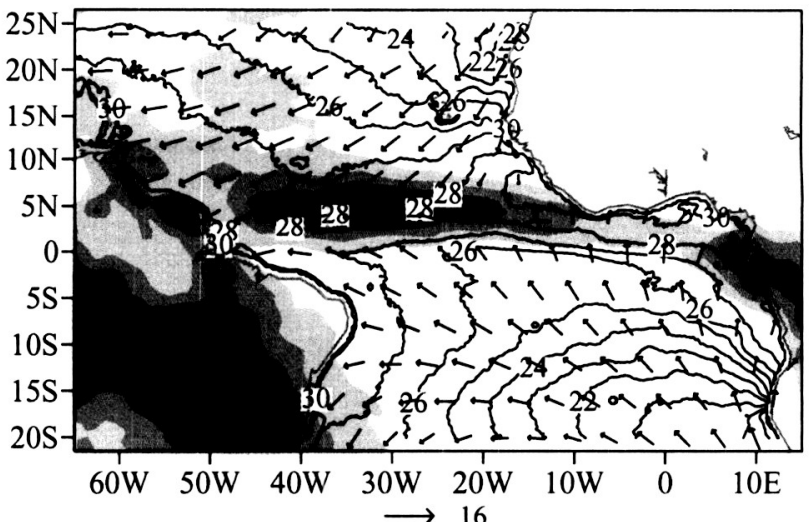

Figure 2: Monthly mean rainfall $\left(m m\right.$ day $\left.{ }^{-1}\right)$ from $3 \mathrm{~B} 43$ (color shades), TMI SST $\left({ }^{\circ} C\right.$; contours), and QuickScat wind vectors $\left(\mathrm{ms}^{-1}\right.$, only from 2000 to 2002) in the Atlantic-West African sector. Wind vectors of magnitudes $<0.5 \mathrm{~ms}^{-1}$ are not plotted. 
Precipitation and Wind
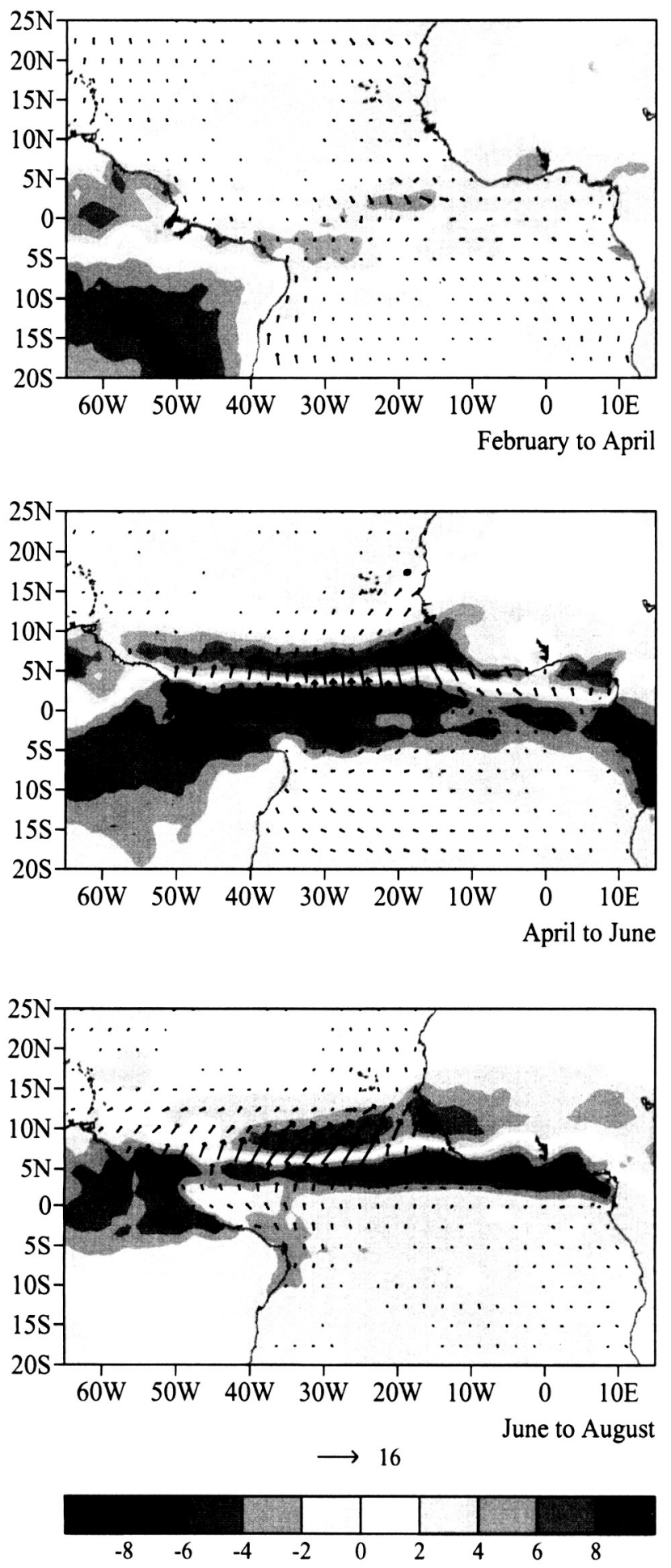

SST and Wind
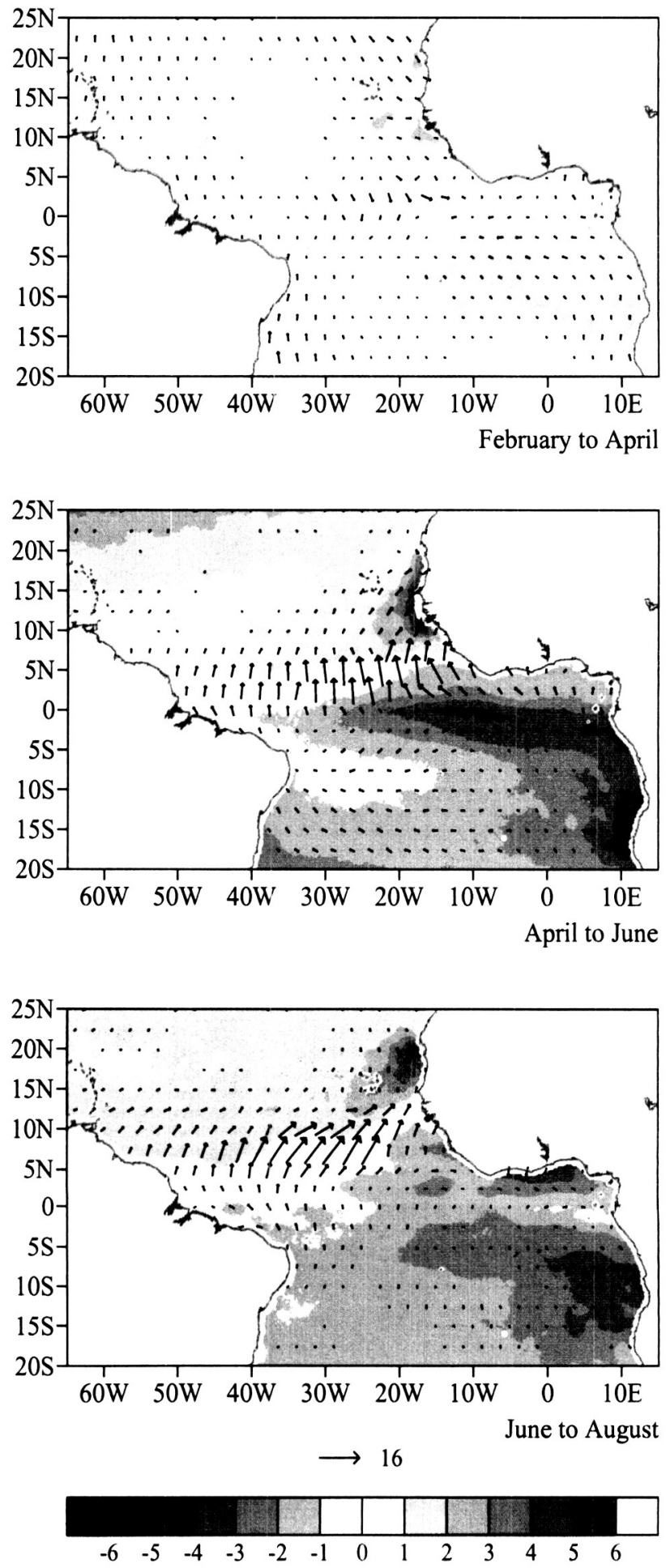

Figure 3: Monthly changes in mean rainfall $\left(m m d a y^{-1}\right)$ from 3 B43, TMI SST $\left({ }^{\circ} C\right)$ and QuickScat wind vectors ( $m s^{-1}$; only from 2000 to 2002 ) in the Atlantic-African sector. Wind change vectors of magnitudes $<0.5 \mathrm{~ms}^{-1}$ are not plotted. 
(a) P and SST

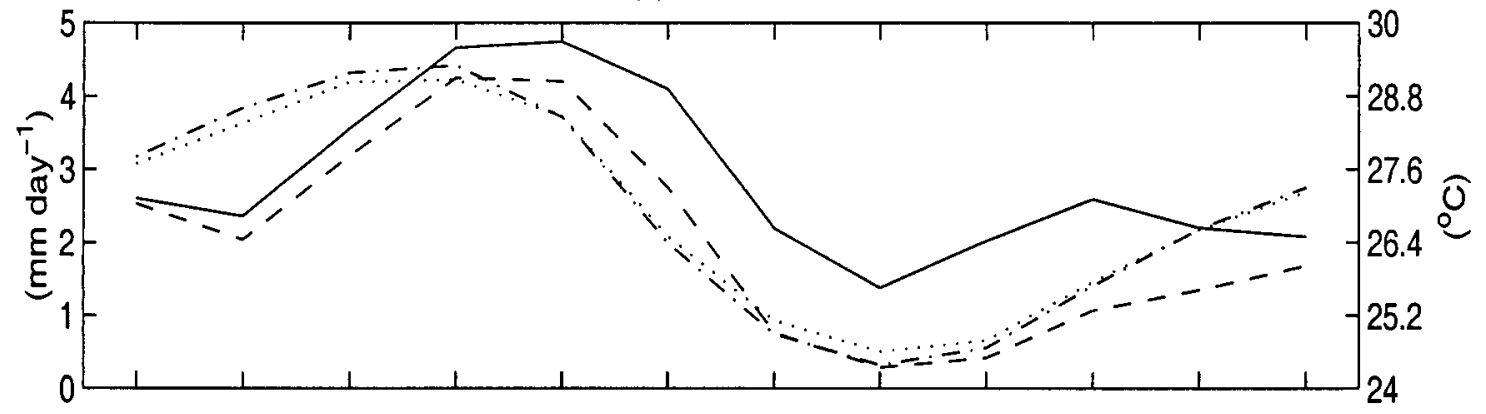

(b) VW and LW

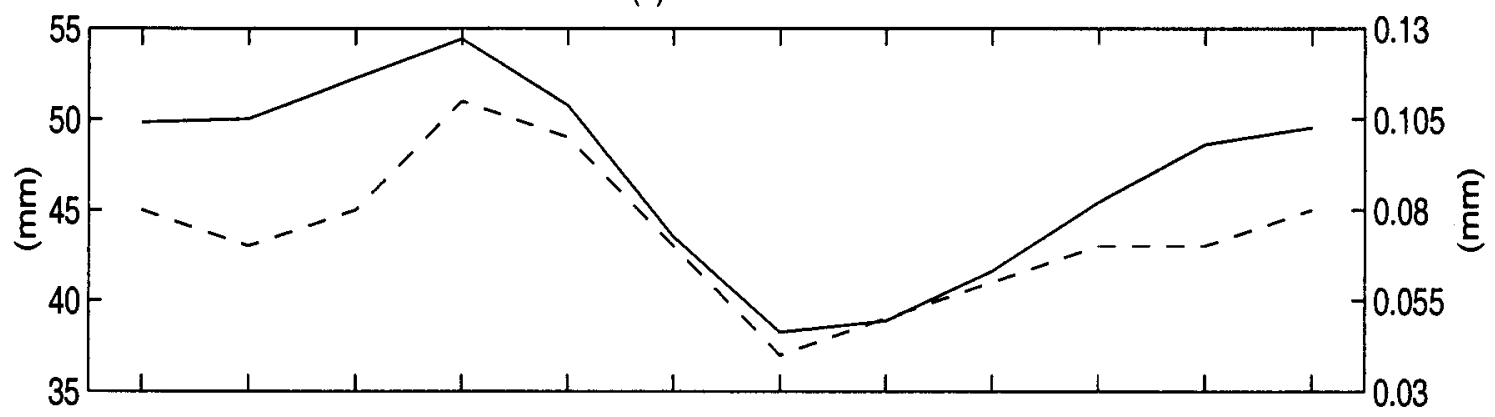

(c) U and $\mathrm{V}$

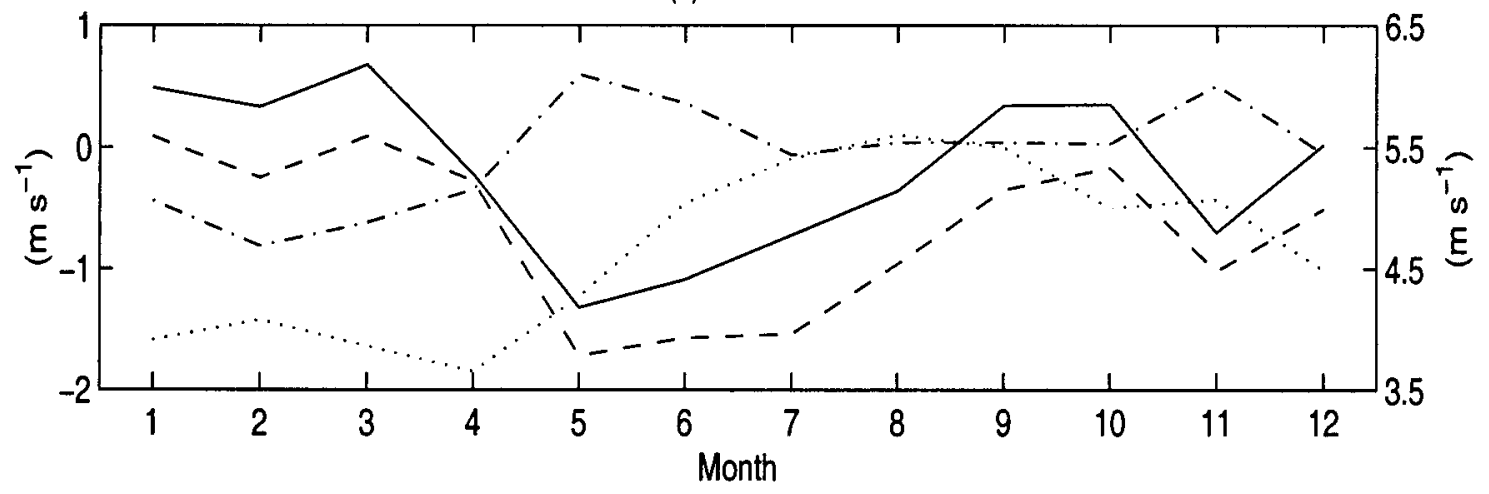

Figure 4: Seasonal cycles in (a) rainfall $\left[P\left(m m d^{-1}\right)\right]$ from $3 \mathrm{~B} 43\left[4.5^{\circ} \mathrm{S}-6.5^{\circ} \mathrm{N}, 9.5^{\circ} \mathrm{W}-\right.$ $9.5^{\circ} \mathrm{E}$ (solid line); $4.5^{\circ} \mathrm{S}-4.5^{\circ} \mathrm{N}, 9.5^{\circ} \mathrm{W}-5.5^{\circ} \mathrm{E}$ (dashed line)], TMI SST $\left({ }^{\circ} \mathrm{C}\right)\left(4.125^{\circ} \mathrm{S}-\right.$ $4.125^{\circ} \mathrm{N}, 10.125^{\circ} \mathrm{W}-5.125^{\circ} \mathrm{E}$; dashdot line), and Reynolds and Smith SST $\left({ }^{\circ} \mathrm{C}\right)\left(4.5^{\circ} \mathrm{S}-\right.$ $4.5^{\circ} \mathrm{N}, 9.5^{\circ} \mathrm{W}-4.5^{\circ} \mathrm{E}$; dotted line), (b) TMI columnar water vapor ( $V W(\mathrm{~mm})$; solid line) and cloud liquid water $[L W(m m)$; dashed line $]\left(4.125^{\circ} S-4.125^{\circ} \mathrm{N}, 10.125^{\circ} \mathrm{W}-5.125^{\circ} \mathrm{E}\right)$, and (c) QuickScat zonal $\left(U\left(\mathrm{~m} \mathrm{~s}^{-1}\right)\right.$; solid line) and meridional winds $\left[V\left(\mathrm{~m} \mathrm{~s}^{-1}\right)\right.$; dashdot line] $\left(4.125^{\circ} \mathrm{S}-4.125^{\circ} \mathrm{N}, 10.125^{\circ} \mathrm{W}-5.125^{\circ} \mathrm{E}\right)$, and NCEP/NCAR $1000 \mathrm{mb}$ zonal $[U(\mathrm{~m}$ $\left.\mathrm{s}^{-1}\right)$; dashed line] and meridional winds $\left[V\left(\mathrm{~m} \mathrm{~s}^{-1}\right)\right.$; dotted line] $\left(5^{\circ} S-5^{\circ} \mathrm{N}, 10^{\circ} \mathrm{W}-5^{\circ} \mathrm{E}\right)$. (c) is only from 2000 to 2002 . 
(a)

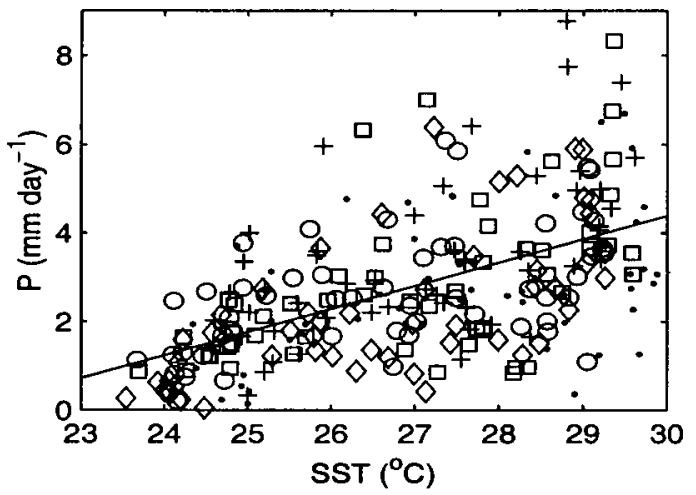

(c)

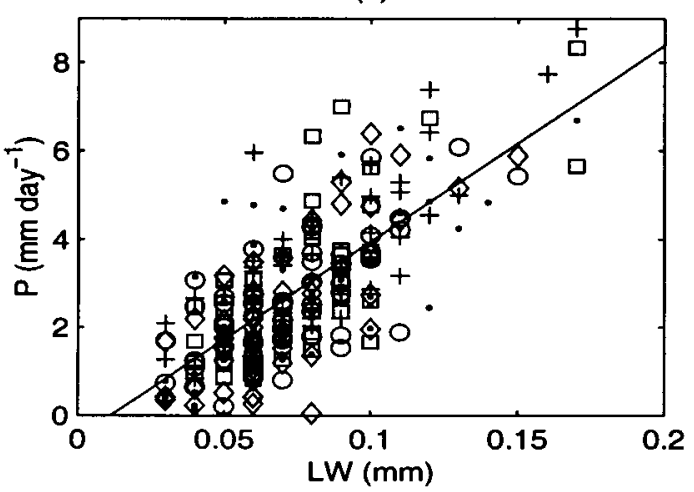

(e)

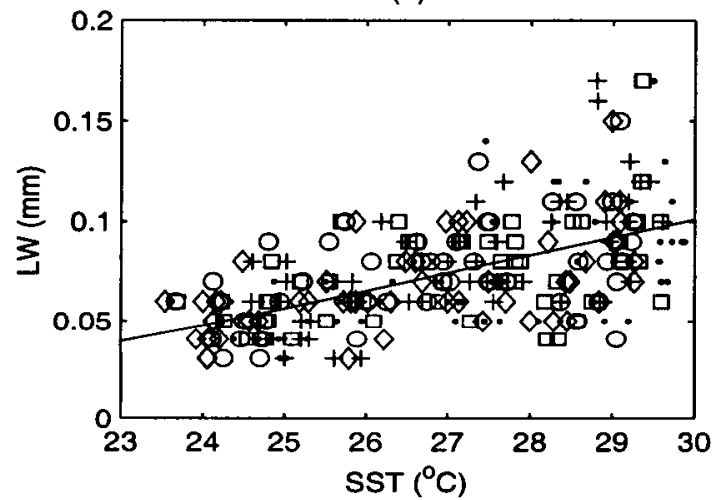

(b)

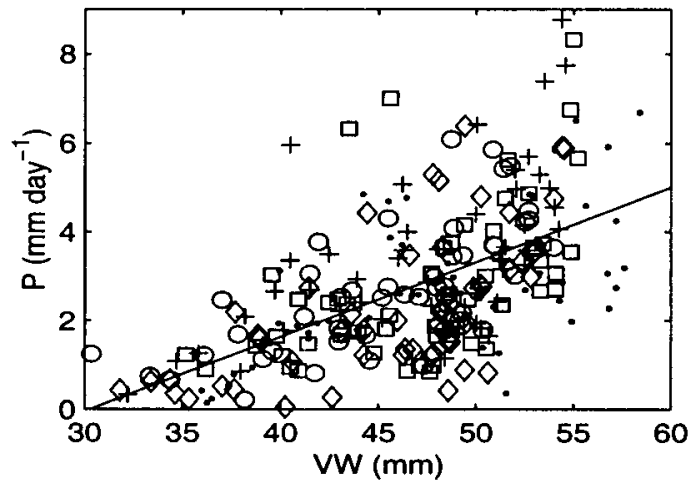

(d)

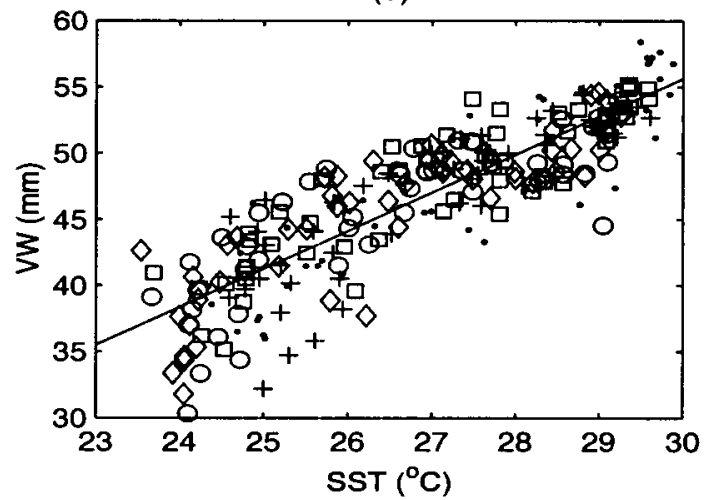

(f)

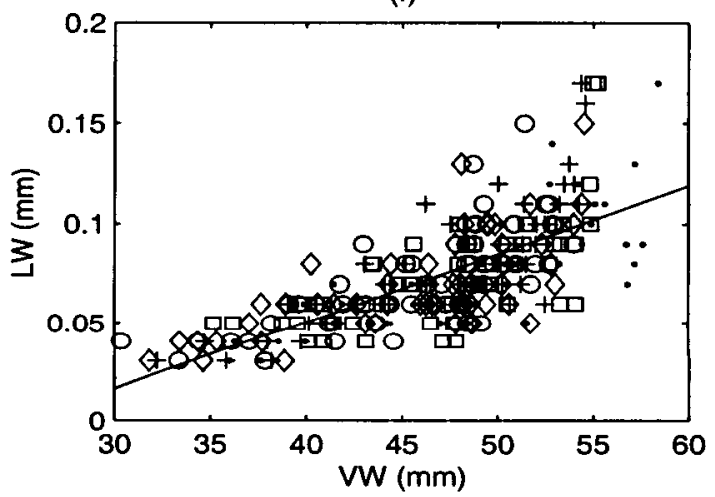

Figure 5: Scattergrams of weekly rainfall $\left[P\left(m m d^{2} a y^{-1}\right) ; 4.5^{\circ} S-6.5^{\circ} N, 9.5^{\circ} W-9.5^{\circ} E\right)$, TMI SST $\left[{ }^{\circ} \mathrm{C} ; 4.125^{\circ} \mathrm{S}-4.125^{\circ} \mathrm{N}, 10.125^{\circ} \mathrm{W}-5.125^{\circ} \mathrm{E}\right]$, columnar water $\left[V W(\mathrm{~mm}) ; 4.125^{\circ} \mathrm{S}-\right.$ $\left.4.125^{\circ} \mathrm{N}, 10.125^{\circ} \mathrm{W}-5.125^{\circ} \mathrm{E}\right]$, and cloud liquid water $\left[\mathrm{LW}(\mathrm{mm}) ; 4.125^{\circ} \mathrm{S}-4.125^{\circ} \mathrm{N}\right.$, $\left.10.125^{\circ} \mathrm{W}-5.125^{\circ} \mathrm{E}\right]$. Dots are for 1998 , crosses for 1999 , circles for 2000 , diamonds for 2001 , and squares for 2002 . 


\section{(a) Precipitation}
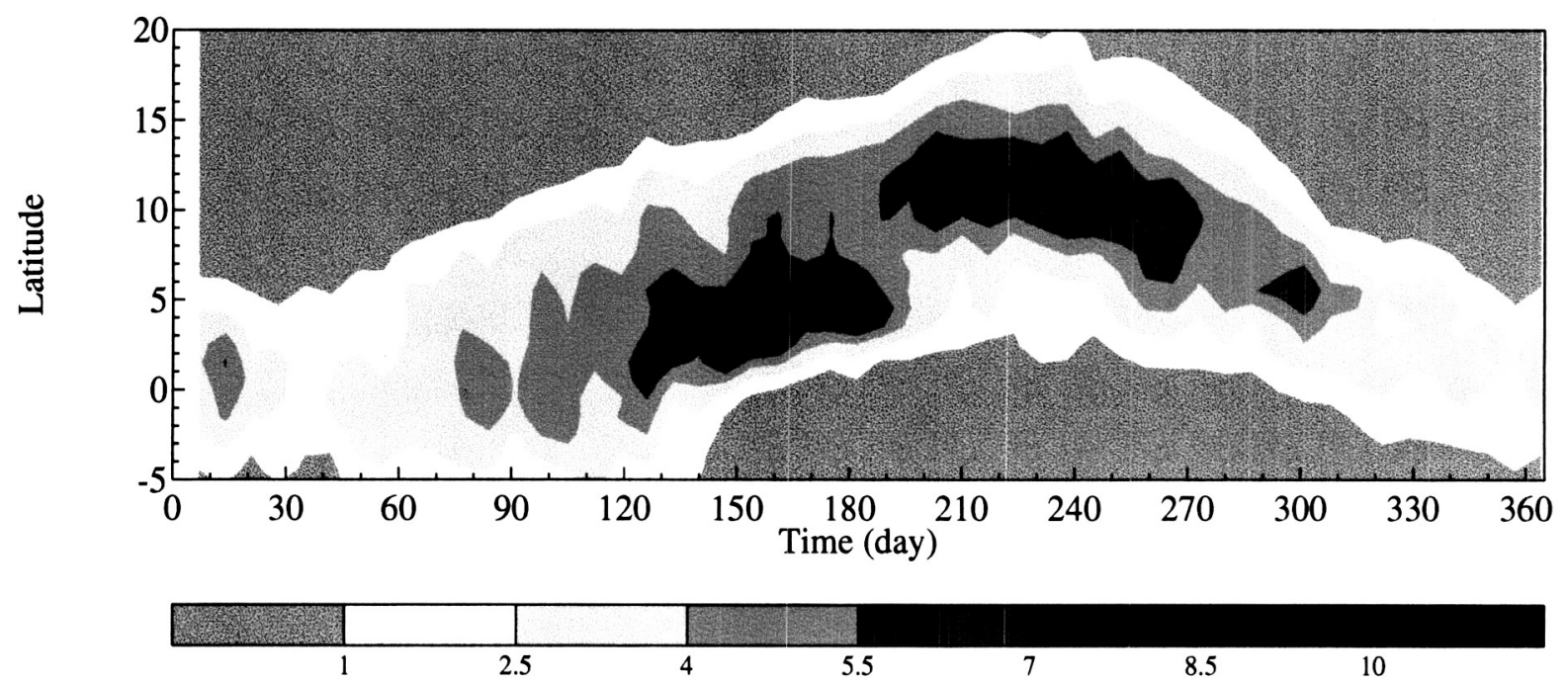

(b) SST

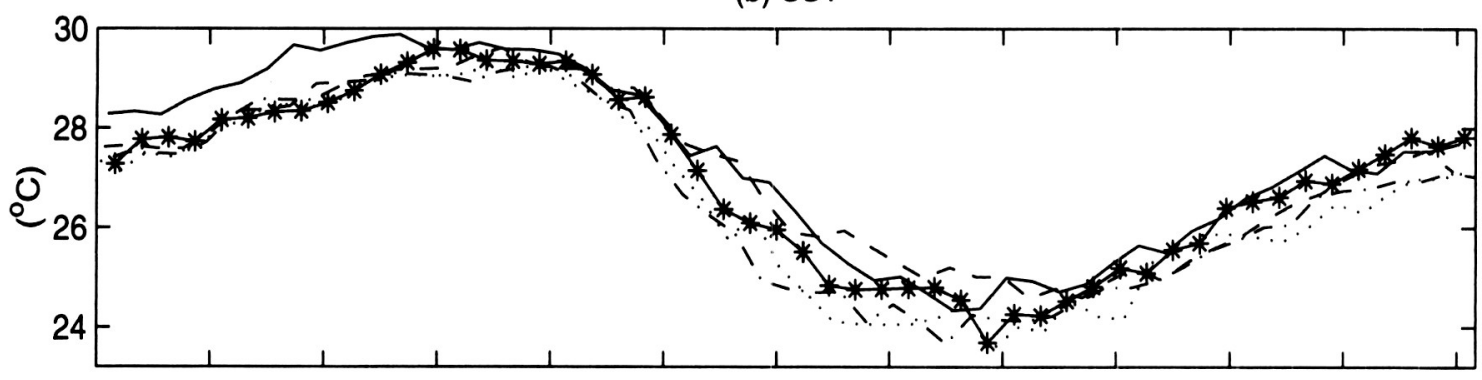

(c) SST Gradient

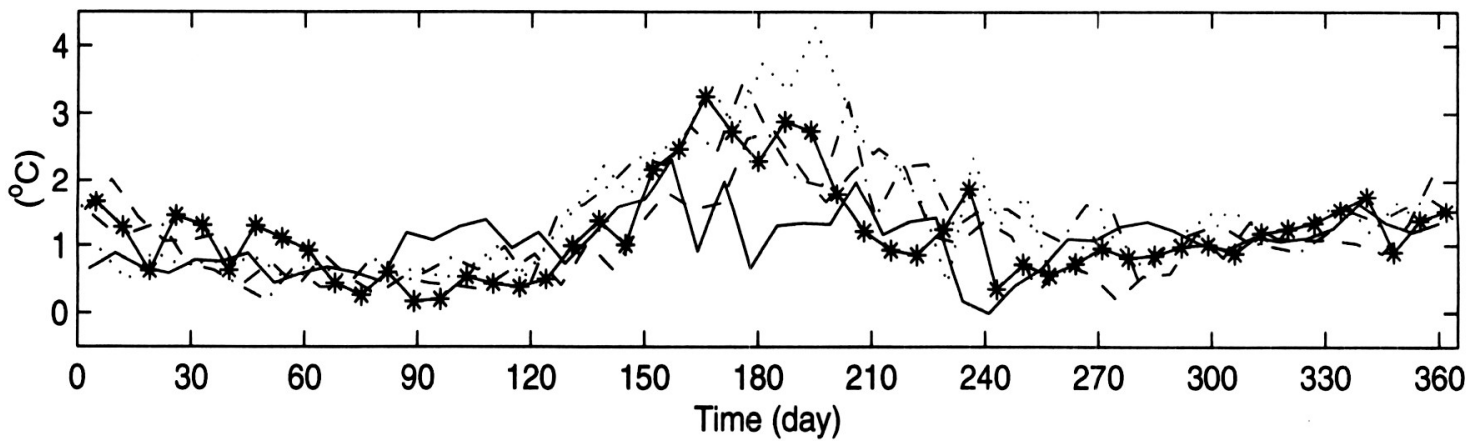

Figure 6: Seasonal cycles in (a) weekly rainfall $\left(m m d a y^{-1}\right)$ between $9.5^{\circ} W-9.5^{\circ} E$, (b) weekly TMI SST $\left[{ }^{\circ} C ; 4.125^{\circ} S-4.125^{\circ} N, 10.125^{\circ} \mathrm{W}-5.125^{\circ} \mathrm{E}\right.$ ], and (c) weekly TMI SST differences between $2.125^{\circ} \mathrm{N}$ and $0.125^{\circ} \mathrm{S}$, averaged along $10.125^{\circ} \mathrm{W}-5.125^{\circ} \mathrm{E}$. In (b) and (c), solid lines are for 1998, dashed lines for 1999, dashdot lines for 2000, dotted lines for 2001 , and star lines for 2002 . 
(a) U

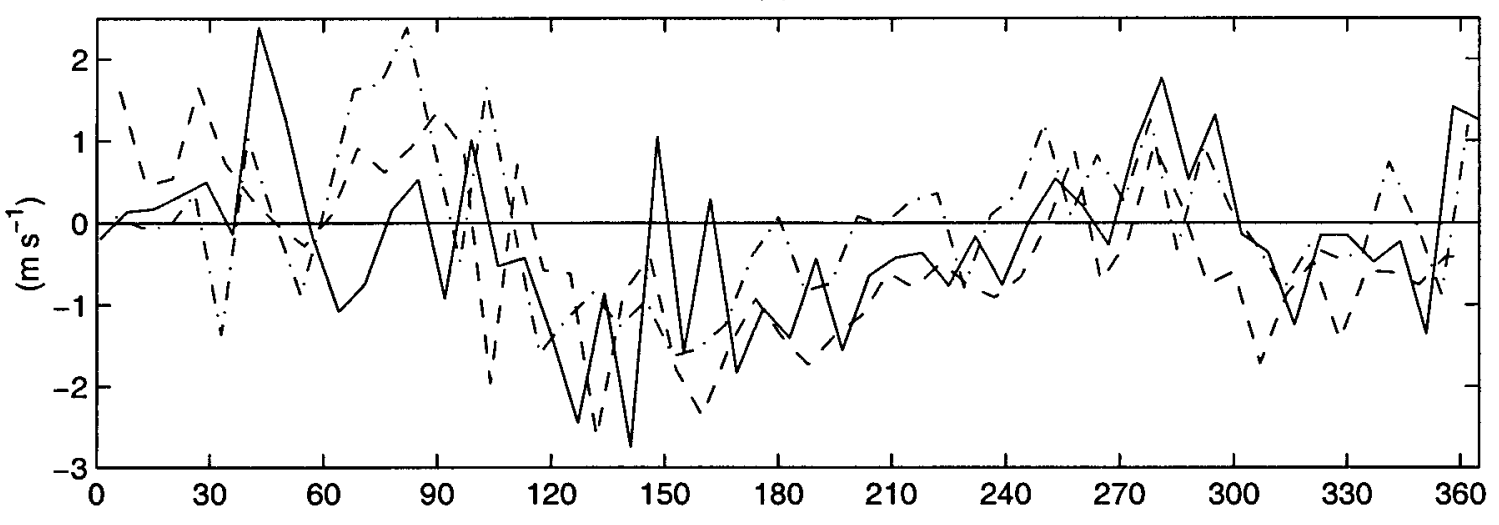

(b) $\mathrm{V}$

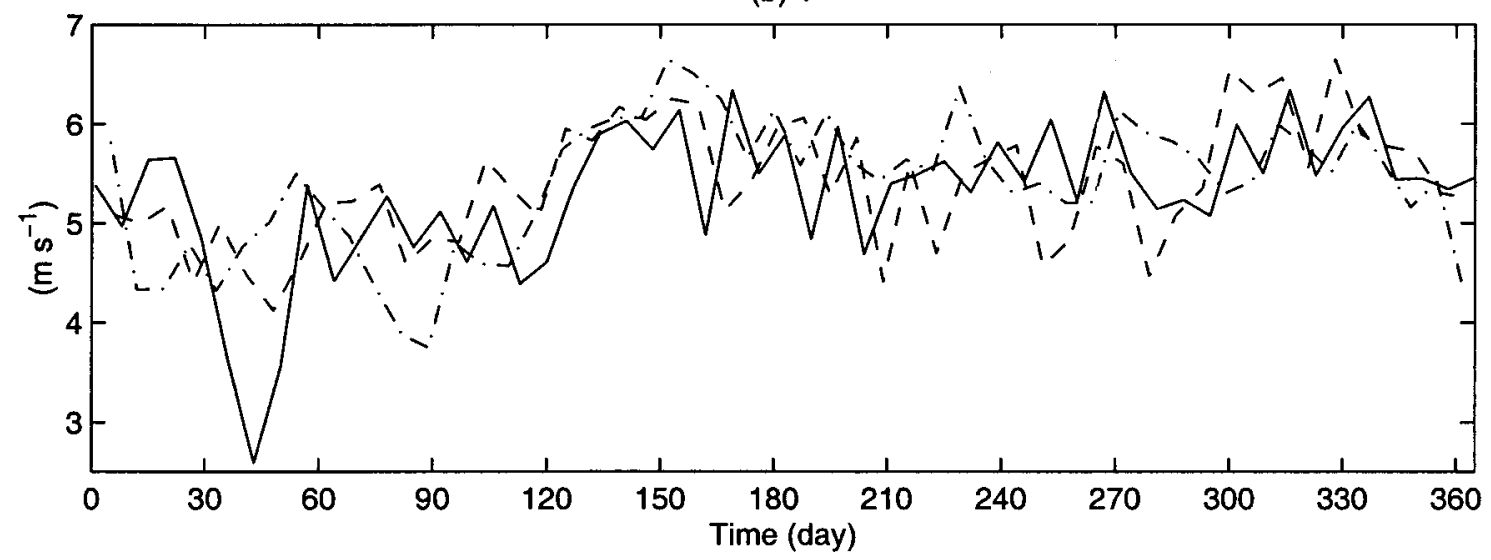

(c)

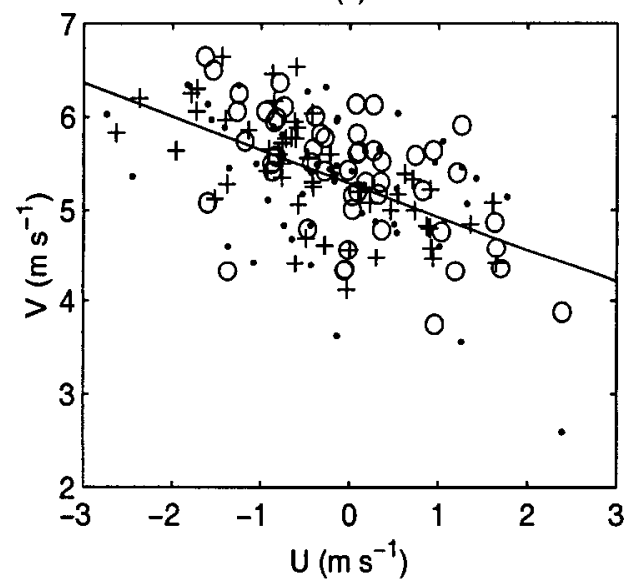

Figure 7: Weekly mean (a) zonal $(U)$ and meridional $(V)$ wind components $\left(m\right.$ day $\left.^{-1}\right)$ within $4.125^{\circ} \mathrm{S}-4.125^{\circ} \mathrm{N}, 10.125^{\circ} \mathrm{W}-5.125^{\circ} \mathrm{E}$ from QuickScat as function of time; Solid lines are for 2000, dashed lines for 2001, and dashdot lines for 2002. (c) Scattergram of wind components; Dots are for 2000, crosses for 2001, circles for 2002. 
March - June
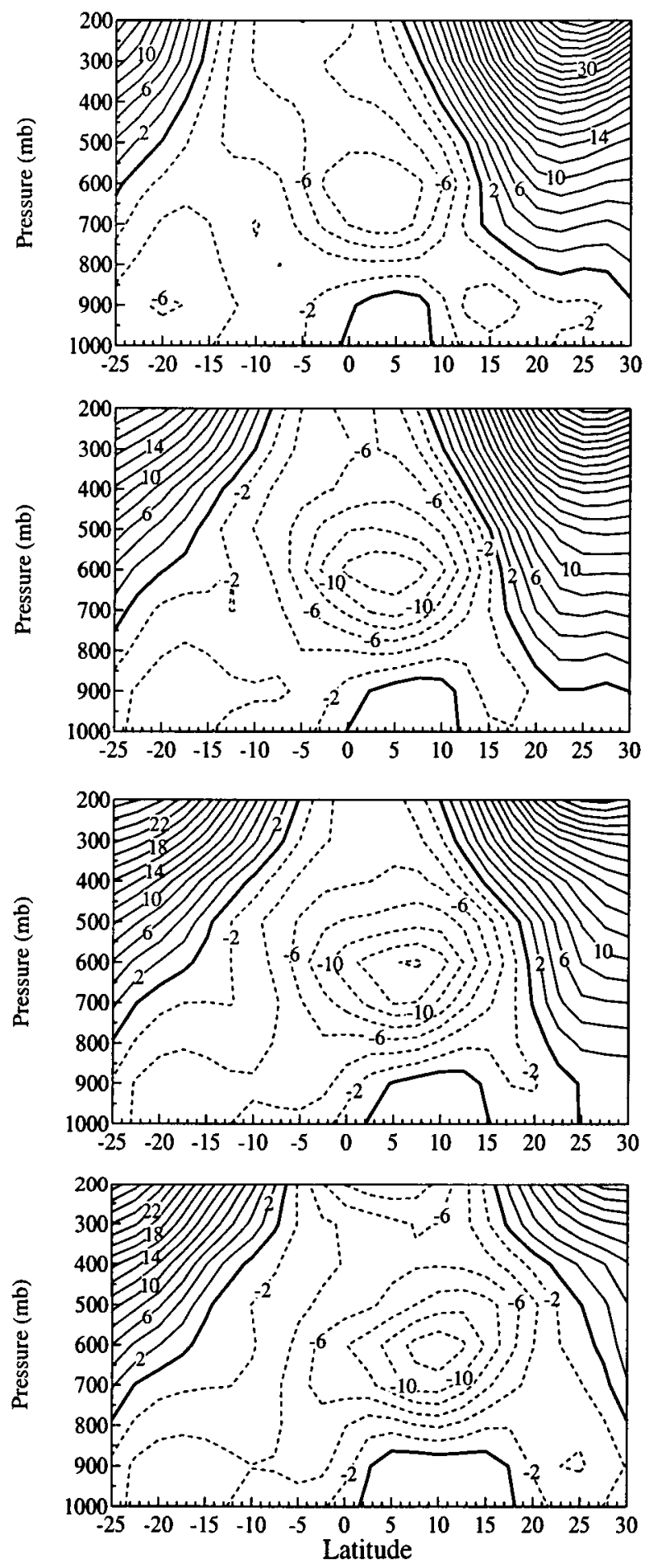

July - October
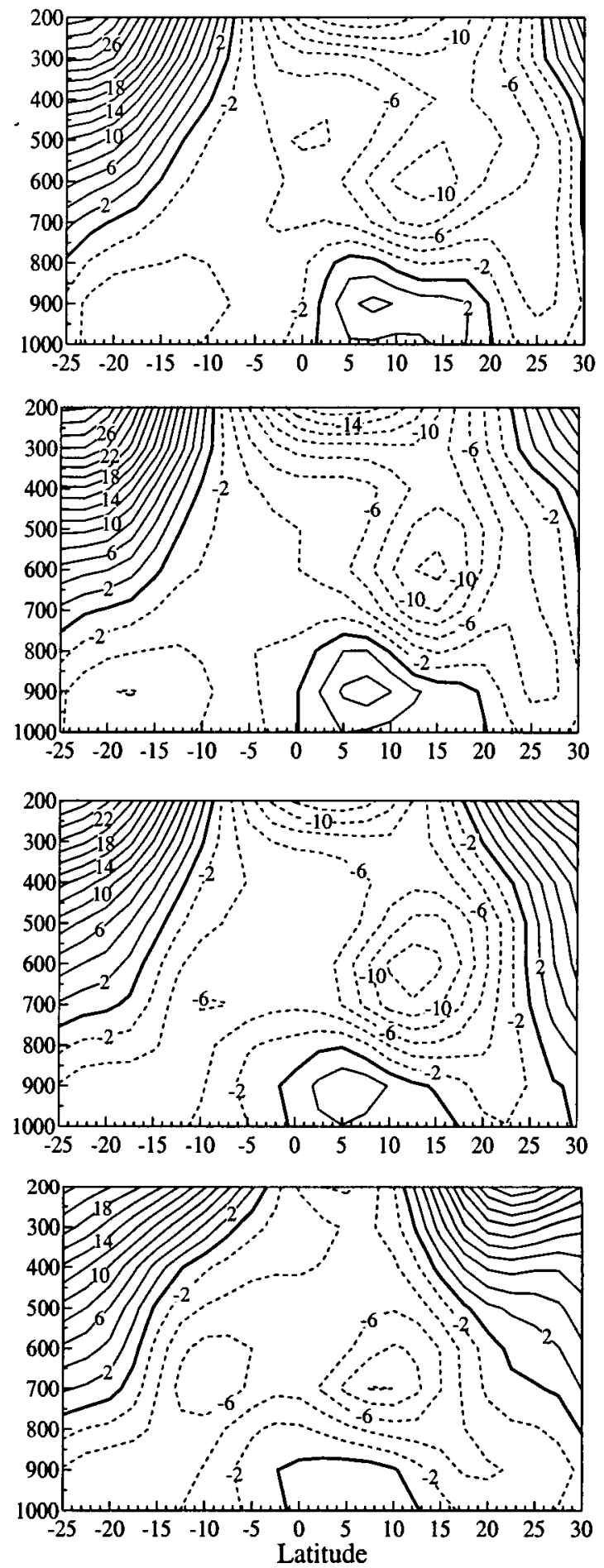

Figure 8: Monthly-mean zonal wind component $\left(m s^{-1}\right)$ from NCEP/NCAR Reanalysis Project between $10^{\circ} \mathrm{W}-10^{\circ} \mathrm{E}(1998-2002)$ as function of pressure and latitude. 
March - June
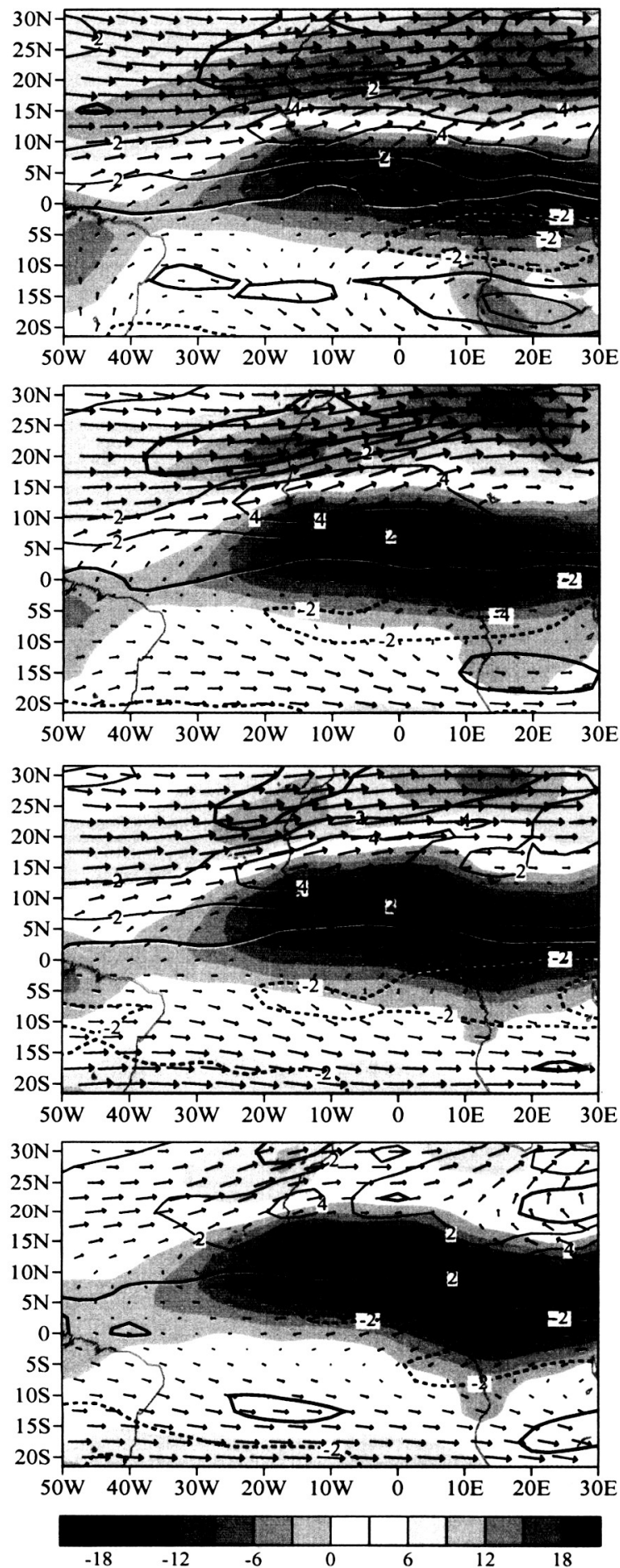

July - October
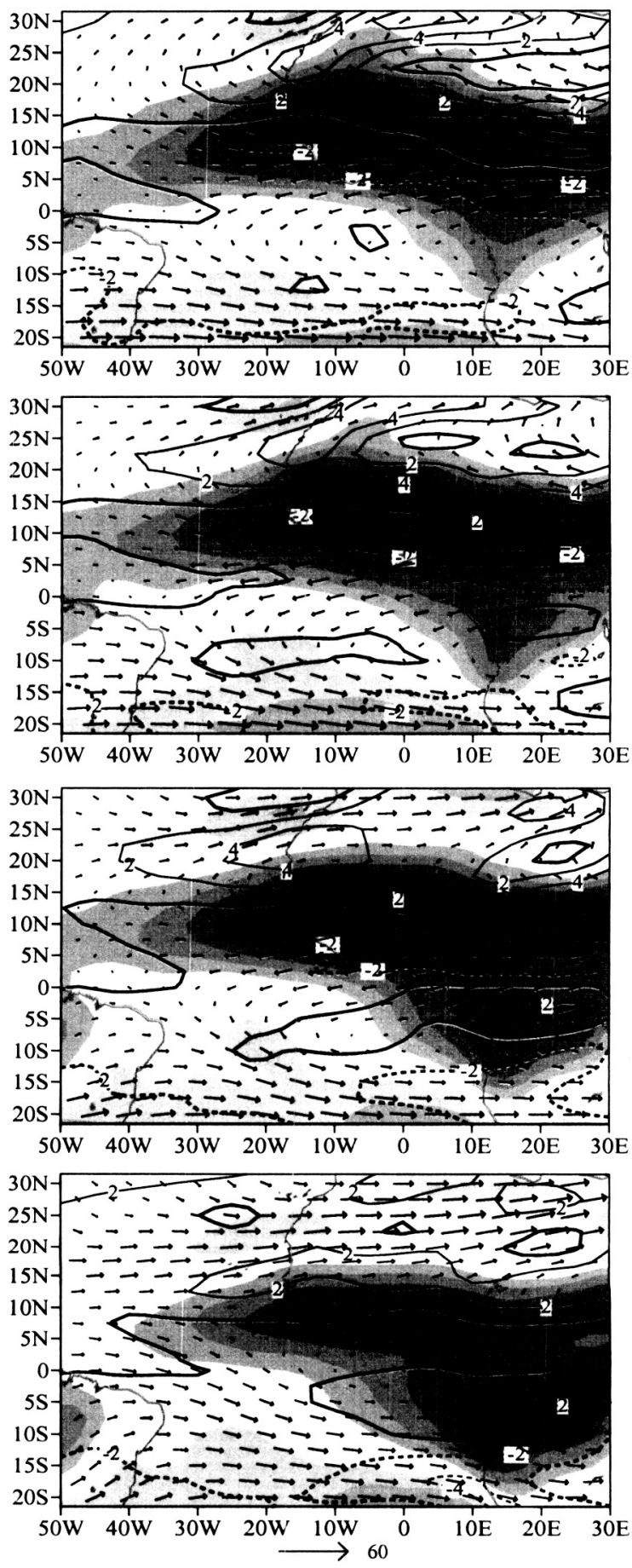

Figure 9: Difference between monthly-mean zonal wind components $\left(\mathrm{ms}^{-1}\right)$ at $600 \mathrm{mb}$ and $925 \mathrm{mb}$ (color shades), meridional shear of monthly-mean zonal wind at $600 \mathrm{mb}$ (proportional to $s^{-1}$; contours), and wind vectors at $150 \mathrm{mb}$ from NCEP/NCAR Reanalysis Project (wind vectors of magnitude $<0.5 \mathrm{~ms}^{-1}$ are not plotted) (1998-2002). 
(a) Precipitation
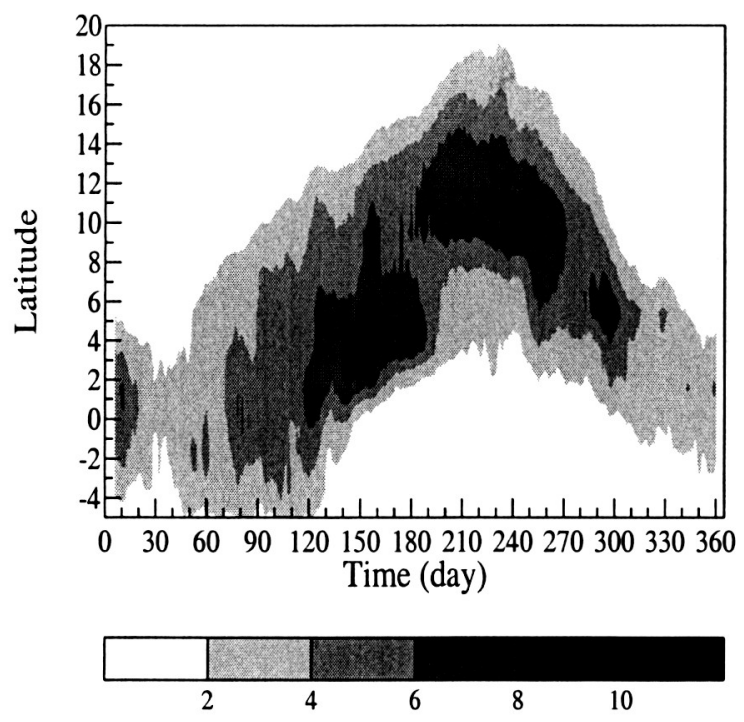

(c) $\mathrm{U}(600 \mathrm{mb})$

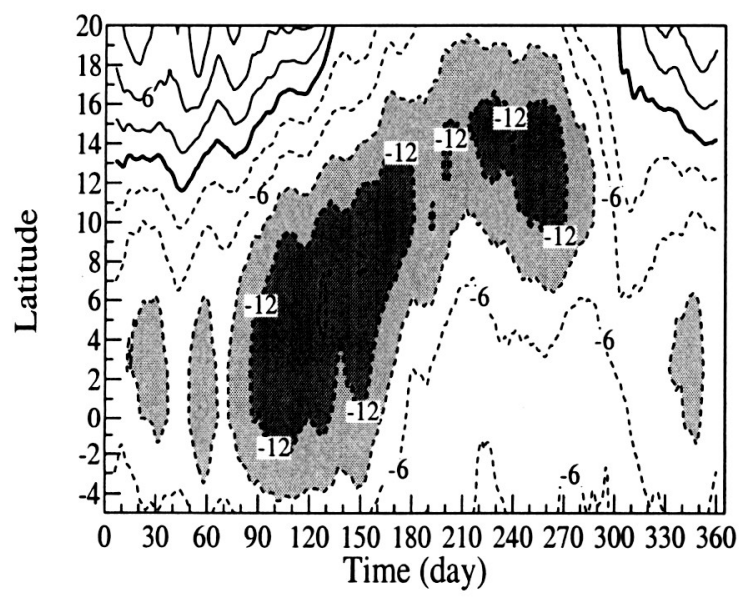

(b) U $(850 \mathrm{mb})$

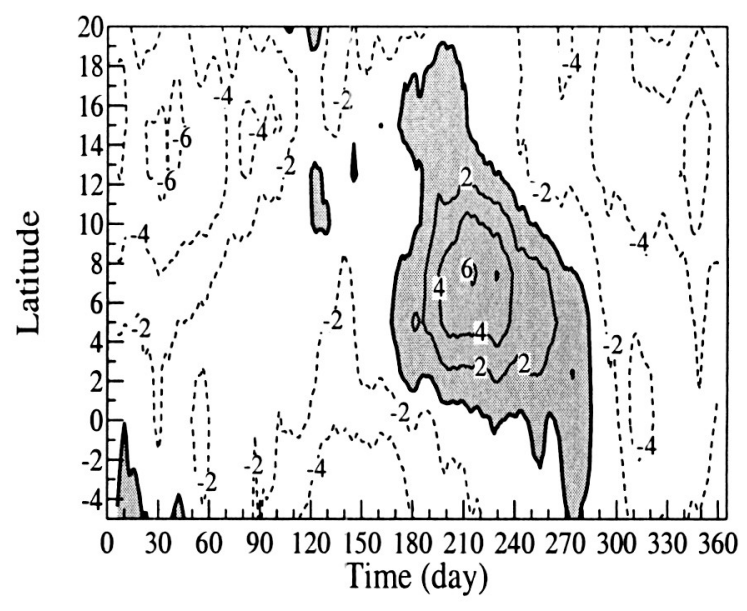

(d) $\mathrm{U}(150 \mathrm{mb})$

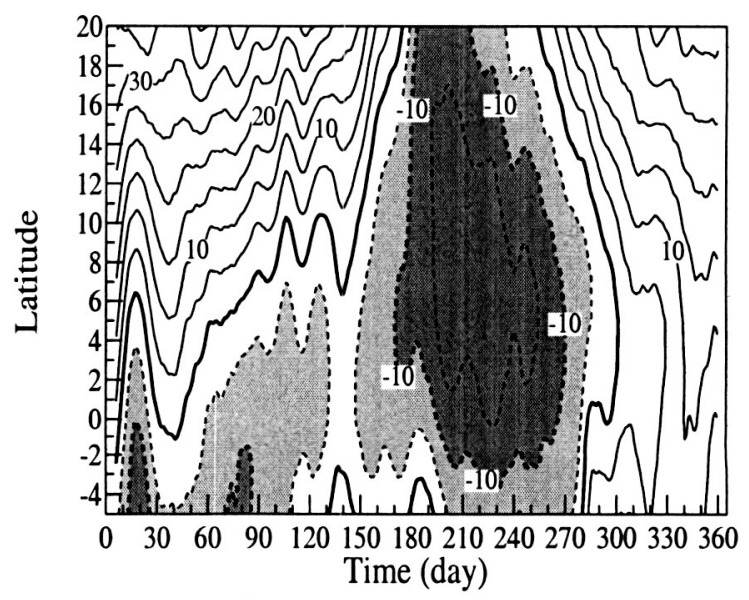

Figure 10: Seasonal cycles in (a) daily rainfall $\left(m m\right.$ day ${ }^{-1} ; 10$-day running mean) from 3B42 between $9.5^{\circ} \mathrm{W}-9.5^{\circ} \mathrm{E}$, and daily zonal wind components $\left(\mathrm{ms}^{-1} ; 10\right.$-day running mean) from NCEP/NCAR Reanalysis Project at (b) $850 \mathrm{mb}$, (c) $600 \mathrm{mb}$ and (d) $150 \mathrm{mb}$ between $10^{\circ} \mathrm{W}-10^{\circ} \mathrm{E}$. 
April
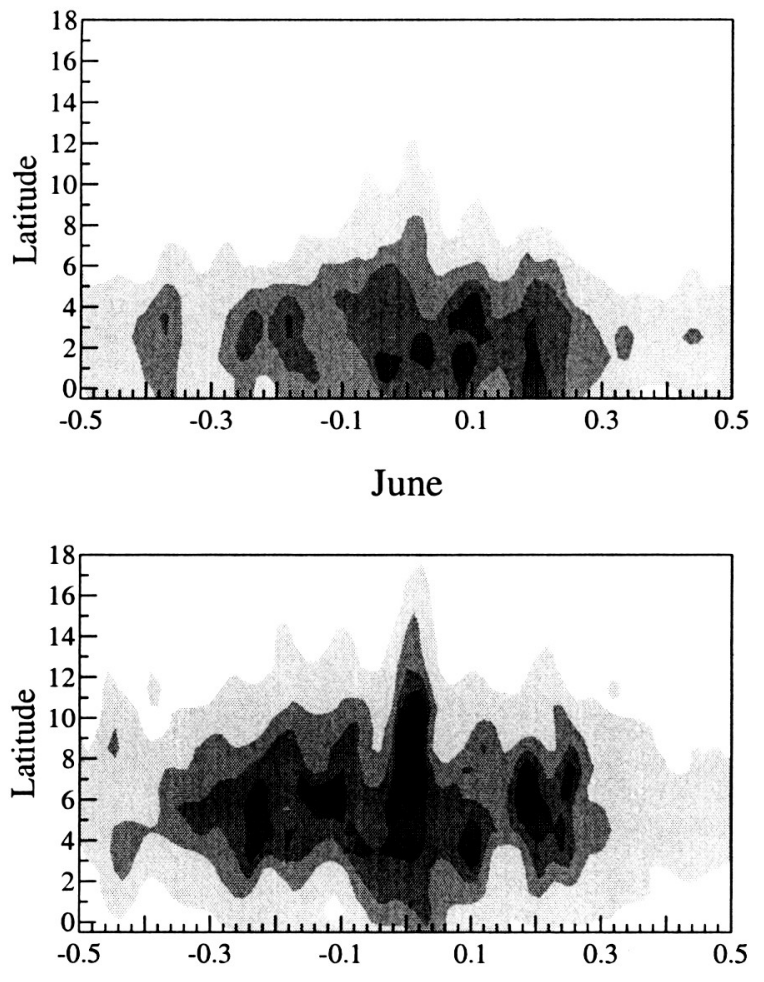

August
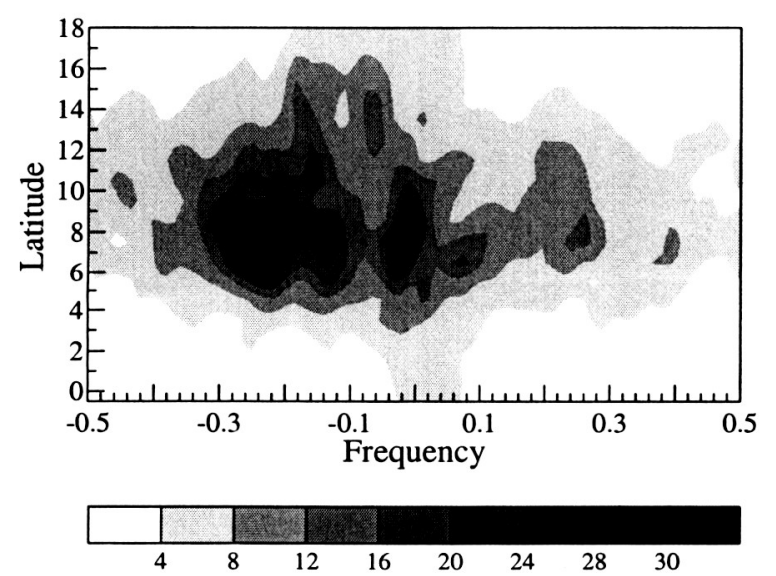

May
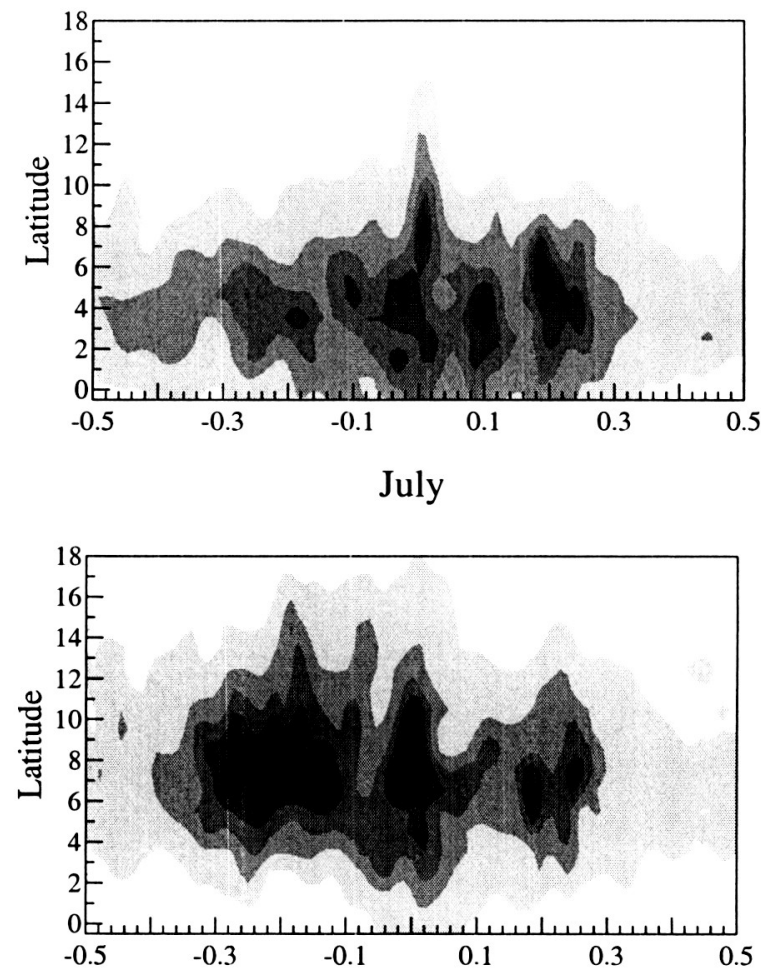

September

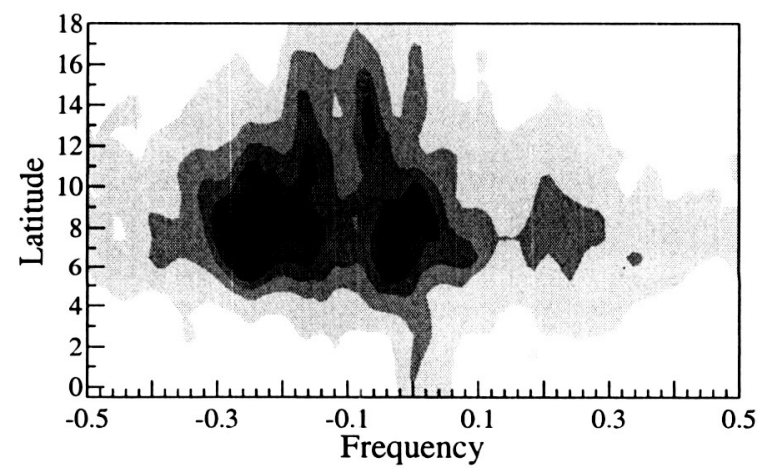

Figure 11: Mean spectral power $\left(\mathrm{mm}^{2} \mathrm{day}^{-2}\right.$; wavenumber $\left.k=6-10\right)$ of rainfall from $3 \mathrm{~B} 42$ between $9.5^{\circ} \mathrm{W}-9.5^{\circ} \mathrm{E}$ during April-September as function of frequency (cycles day $\left.{ }^{-1}\right)$ and latitude. Positive (negative) frequencies represent eastward (westward) components. 
(a) April - June

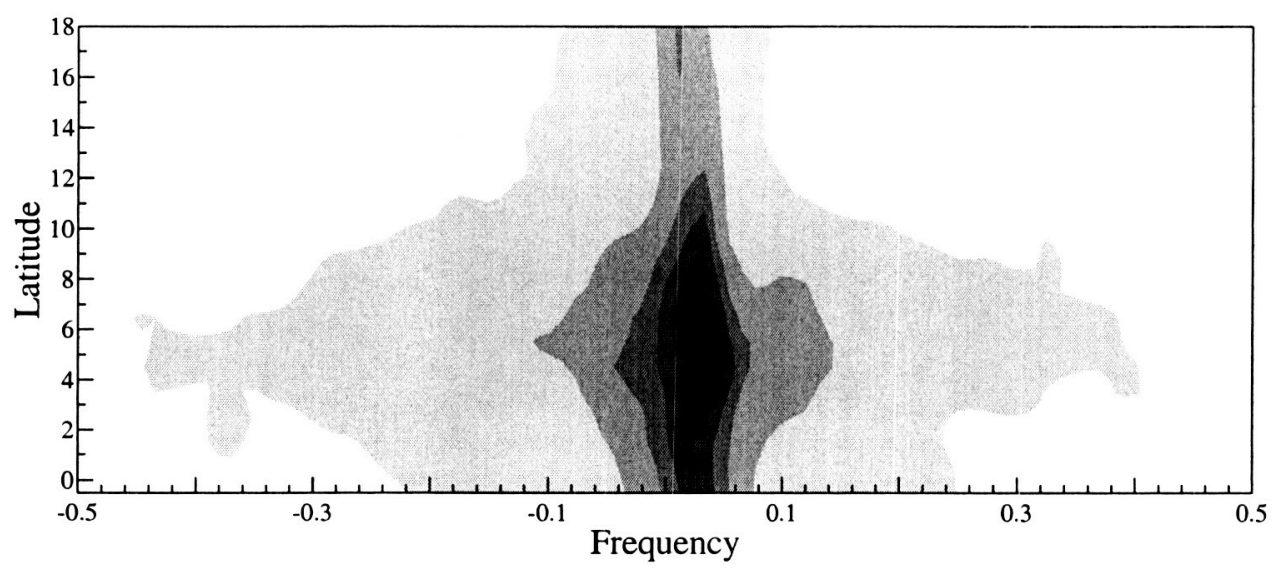

(b) July - September

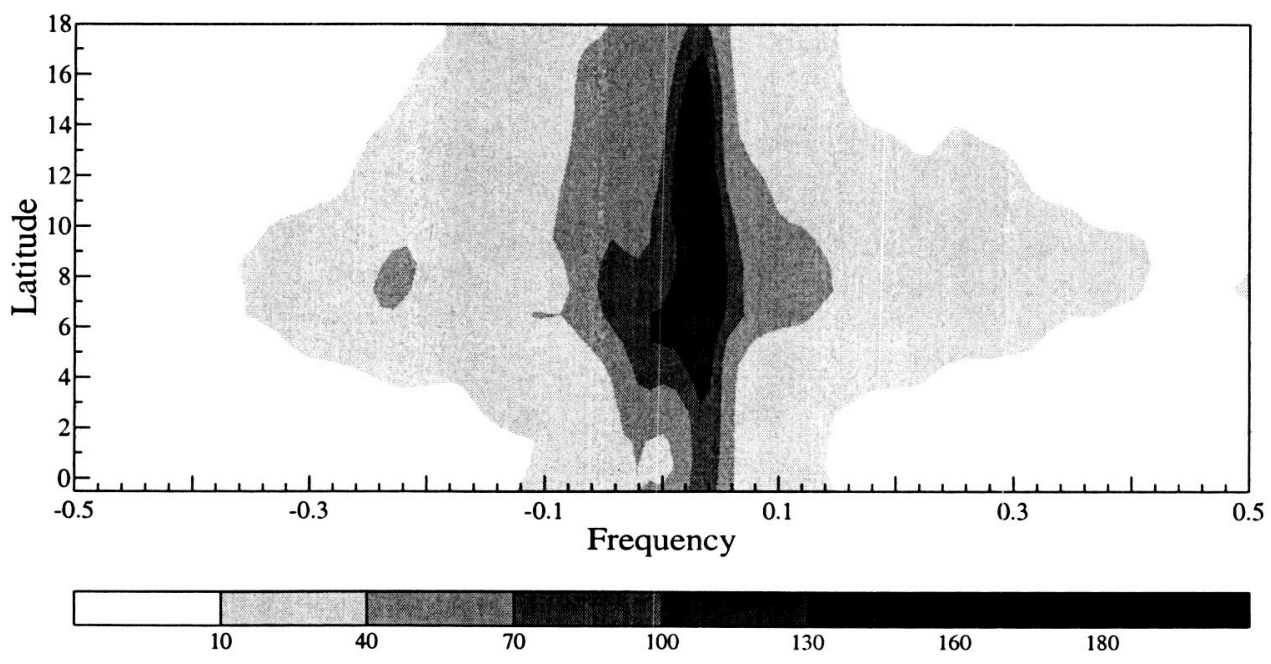

Figure 12: Mean spectral power $\left(\mathrm{mm}^{2} \mathrm{day}^{-2}\right)$ of rainfall from $3 \mathrm{~B} 42$ between $9.5^{\circ} \mathrm{W}-9.5^{\circ} \mathrm{E}$ for $k=1-5$ during (a) April-June and (b) July-September as function of frequency (cycles $d a y^{-1}$ ) and latitude. Positive (negative) frequencies represent eastward (westward) components. 
(a) U

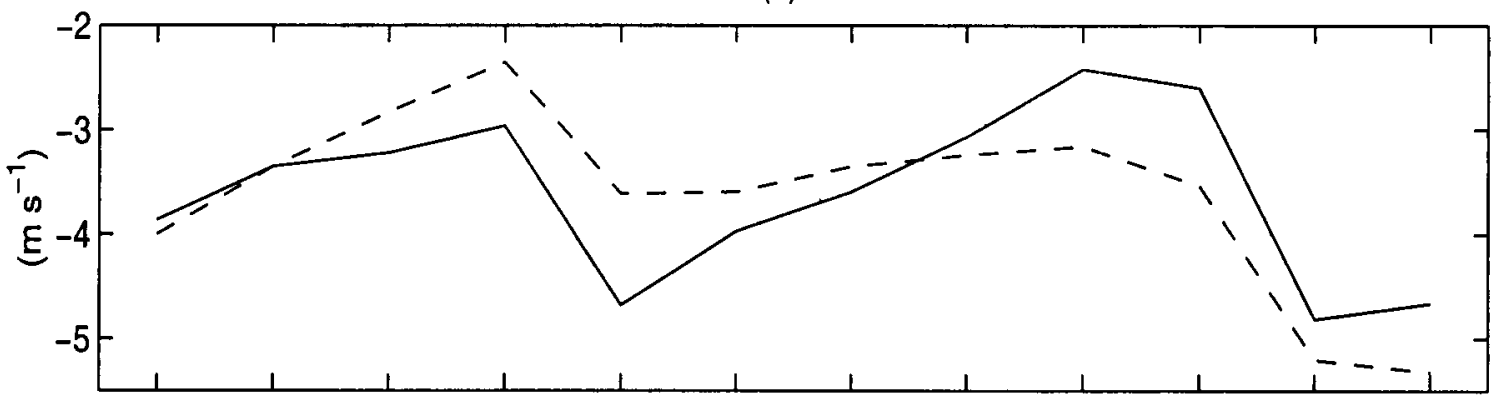

(b) V

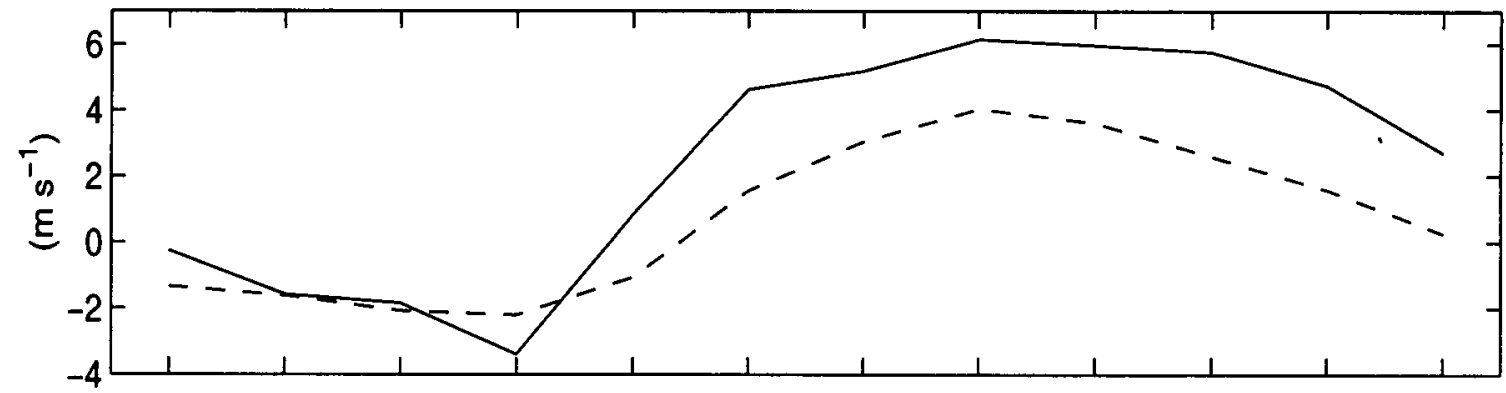

(c) Differences

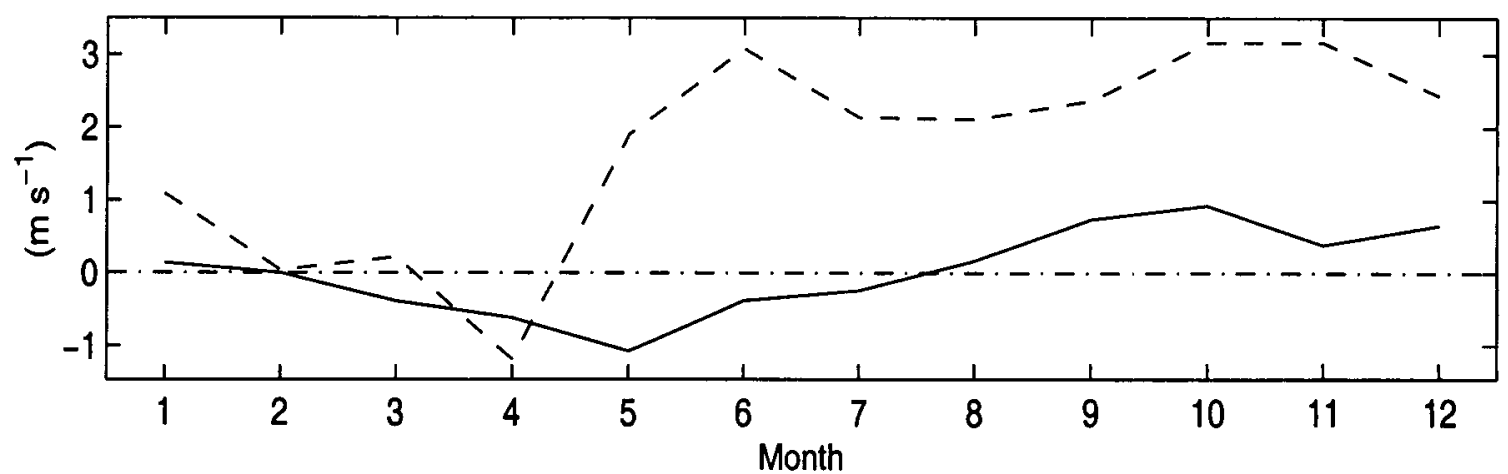

Figure A1: Monthly mean QuickScat $\left(\mathrm{ms}^{-1}\right.$; solid lines in (a) and (b); $0.125^{\circ} \mathrm{N}-5.125^{\circ} \mathrm{N}$, $\left.30.125^{\circ} \mathrm{W}-20.125^{\circ} \mathrm{W}\right)$ and NCEP/NCAR $1000 \mathrm{mb}$ wind components $\left(\mathrm{ms}^{-1}\right.$; dashed lines in (a) and (b); $0-5^{\circ} \mathrm{N}, 30^{\circ} \mathrm{W}-20^{\circ} \mathrm{W}$ ) from 2000 to 2002. (a) Zonal wind components; (b) Meridional wind components; (c) The differences between QuickScat and NCEP/NCAR $1000 \mathrm{mb}$ wind components (solid line for zonal wind, dashed line for meridional wind). 